\title{
Intake, digestion and small intestinal protein availability in sheep in relation to ammoniation of wheat straw with or without protein supplementation
}

\author{
BY S. J. OOSTING \\ Department of Animal Husbandry, Section of Tropical Animal Production, Agricultural University, \\ PO Box 338, NL 6700 AH Wageningen, The Netherlands
}

AND J. VAN BRUCHEM

Department of Animal and Human Physiology, Agricultural University, Haarweg 10, NL 6709 PJ Wageningen, The Netherlands

AND X. B. CHEN

The Rowett Research Institute, Greenburn Road, Bucksburn, Aberdeen AB2 9SB

(Received 23 February 1994 - Revised 13 December 1994-Accepted 6 January 1995)

\begin{abstract}
The effects of ammoniation of wheat straw with or without supplementation of protein sources of either high (casein) or relatively low (potato protein) rumen degradability on intake and digestion were studied with four sheep in a $4 \times 4$ Latin square design. Rations offered were: (1) untreated wheat straw (UWS), (2) ammoniated wheat straw (AWS), (3) AWS supplemented with $3.2 \mathrm{~g}$ casein/kg live weight (W) ${ }^{0.75}$ per d (AWSC) and (4) AWS supplemented with $3.9 \mathrm{~g}$ potato protein/kg $\mathrm{W}^{0.75}$ per d (AWSP). Straw was offered $a d$ lib. and all rations were supplemented with sugarbeet pulp and a mineral mixture. $\mathrm{NH}_{3}$ treatment increased intake and digestion. Supplementation of AWS with potato protein increased total digestible organic matter intake (DOMI) compared with AWS whereas supplementation with casein did not affect total DOMI. Protein supplementation of AWS significantly reduced rumen digestion of cellulose, and when the supplementation was with casein it reduced rumen digestion of neutral-detergent fibre and hemicellulose also. This lower rumen digestion was compensated by a higher proportion of digestion occurring in the hindgut for hemicellulose $(P<0.05$ for AWSC, $P>0.05$ for AWSP), but not for cellulose. Across all rations, rumen fluid volume increased with increasing cell-wall intake. The efficiencies of microbial protein synthesis were (average of three different methods of estimation) $23.3,26 \cdot 2,34.8$ and $31.7 \mathrm{~g} \mathrm{~N} / \mathrm{kg}$ apparently-rumen-degraded organic matter for UWS, AWS, AWSC and AWSP respectively. The difference between UWS and AWS was not significant, but values for AWSC and AWSP were significantly higher than that for AWS. The rumen digestion of feed amino acid-N (AA-N) was significantly higher for AWSC than for the other rations. The apparent smallintestinal digestion of AA-N and $N$ was significantly higher for AWSP than for the other rations. The true small-intestinal digestion values were $0.86,0.84$ and 0.68 for $A A-N, N$ and non-protein- $N$ respectively. Heal endogenous losses of AA-N were approximately $6 \mathrm{mg} / \mathrm{g}$ duodenal non-protein drymatter flow. Linear relationships were observed between DOMI and $N$ balance and truly absorbed AA$\mathrm{N}$, indicating that DOMI could have been limited by small-intestinal amino acid availability. Regression of $\mathrm{N}$ balance $v$. truly absorbed $\mathrm{AA}-\mathrm{N}$ resulted in an estimate of net efficiency of utilization of truly absorbed AA-N of 0.54.
\end{abstract}

Protein availability: Ammoniated wheat straw: $\mathbf{N}$ balance: Microbial protein synthesis.

In ruminants, roughage intake may be limited by the intestinal supply of amino acids (AA; e.g. Doyle \& McLaren, 1988; Doyle \& Panday, 1990). The availability of AA for 
absorption from the small intestine depends on the amounts of AA entering the duodenum, either from feed or of microbial origin, the amounts of endogenous protein added to the digesta, the true digestibility of the feed and microbial protein, and the proportion of endogenous protein that passes from the ileum to the caecum-colon (Van Bruchem et al. 1989). Limited rumen availability of nutrients such as peptides, branched-chain volatile fatty acids (VFA) and/or minerals in combination with a long retention time of microbes in the rumen may be reasons for the relatively low efficiency of microbial protein synthesis (Hespell \& Bryant, 1979; Hoover, 1986), as found for untreated and ammoniated wheat straw (Oosting et al. 1993 b). However, ileal endogenous AA losses were lower for rations based on untreated and ammoniated wheat straw (Oosting et al. 1993 $b$ ) than for rations based on forages grown under temperate conditions (Van Bruchem $e t$ al. 1989). Hence, major constraints to AA availability in the small intestine for rations with straw as the major component are the low efficiency of microbial protein synthesis in the rumen in combination with a low flow of AA derived from straw, which probably have a low smallintestinal digestibility (Hvelplund, 1989).

The aim of the present experiment was to study the effects of ammoniation of wheat straw and of the supplementation of the ammoniated straw with proteins of low and high rumen degradability on intake, digestion and site of digestion, rumen fermentation and microbial protein synthesis, and small-intestinal AA availability.

\section{MATERIALS AND METHODS \\ Animals, diets and experimental design}

Four sheep (wethers, breed Swifter, a cross-breed of Texel and Flemish) with an average live weight (W) of $61 \mathrm{~kg}$ were fitted with a cannula in the dorsal rumen sac ( $25 \mathrm{~mm}$ i.d.) and with T-shaped cannulas ( $12 \mathrm{~mm}$ i.d.) in the proximal duodenum and terminal ileum. During the experiment the animals were kept in metabolism cages and received equal portions of their ration every $4 \mathrm{~h}$. Water was freely available.

The experiment was set up as a $4 \times 4$ Latin square design. The four diets that were tested were: (1) untreated wheat straw (UWS), (2) ammoniated wheat straw (AWS), (3) AWS supplemented with casein (DMV-Campina, Veghel; AWSC) and (4) AWS supplemented with potato protein (Emsland-Stärke GmbH, Emlichheim, Germany; AWSP). Straw, chopped to a length of approximately $50 \mathrm{~mm}$, was fed ad lib, by offering at least $25 \%$ excess. Ammoniation of the wheat straw was done as described by Oosting et al. (1993a).

All diets were supplemented with sugarbeet pulp, minerals and a commercially available mixture of vitamin A, cholecalciferol and trace elements (Mervit 318; Premervo, Utrecht, The Netherlands). The proportions of constituents in the sugarbeet pulp supplement without additional protein (SBP), with additional casein (SBPC) and with additional potato protein (SBPP) are given in Table 1. Sugarbeet pulp was offered at a level of $16.7 \mathrm{~g}$ $\mathrm{DM} / \mathrm{kg} \mathrm{W}^{0.75}$ per $\mathrm{d}$ and the quantity of the mineral-vitamin mixture offered was $1.8 \mathrm{~g}$ $\mathrm{DM} / \mathrm{kg} \mathrm{W}^{\mathbf{0 . 7 5}}$ per $\mathrm{d}$. Casein and potato protein supplements were given at levels of 3.2 and $3.9 \mathrm{~g} / \mathrm{kg} \mathrm{W}^{0.75}$ per $\mathrm{d}$, respectively. The supplementary casein and potato protein were approximately isonitrogenous. The chemical composition of each of the ration components, including the AA profile, is given in Table 2.

Each of the four experimental periods had a duration of $30 \mathrm{~d}$. The adaptation period before the first experimental period and between experimental periods was $19 \mathrm{~d}$.

\section{Intake and digestion}

Faeces and feed residue were collected for $10 \mathrm{~d}$ starting at day 3 and again at day 17 of each experimental period. No correction was made for withdrawal of digesta from the 
Table 1. Proportions of constituents $(\mathrm{g} / \mathrm{kg})$ in supplements of sugarbeet pulp+minerals and vitamins $(S B P), S B P+$ casein $(S B P C)$ and $S B P+$ potato protein $(S B P P)$

\begin{tabular}{lccc}
\hline & SBP & SBPC & SBPP \\
\hline Sugarbeet pulp & 904 & 742 & 713 \\
Mervit 318 (vitamin A, cholecalciferol and trace elements) & 45 & 37 & 36 \\
$\mathrm{NaH}_{2} \mathrm{PO}_{4} \cdot 2 \mathrm{H}_{2} \mathrm{O}$ & 32 & 26 & 25 \\
$\mathrm{FeSO}_{4} \cdot 7 \mathrm{H}_{2} \mathrm{O}$ & $0 \cdot 5$ & $0 \cdot 4$ & $0 \cdot 4$ \\
$\mathrm{MgSO}_{4} .7 \mathrm{H}_{2} \mathrm{O}$ & 19 & $15 \cdot 6$ & 15 \\
Additional protein & 0 & 178 & 211 \\
\hline \hline
\end{tabular}

Table 2. Chemical composition of wheat straw and protein supplements*

\begin{tabular}{|c|c|c|c|c|c|}
\hline & \multicolumn{2}{|c|}{ Wheat straw } & \multicolumn{3}{|c|}{ Protein supplement } \\
\hline & Untreated & Ammoniated & SBP & SBPC & SBPP \\
\hline $\mathrm{DM}(\mathrm{g} / \mathrm{kg})$ & 910 & 905 & 848 & 816 & 840 \\
\hline Ash (g/kg DM) & 81 & 84 & 94 & 79 & 86 \\
\hline$N(g / k g ~ D M)$ & $5 \cdot 8$ & $13 \cdot 5$ & $14 \cdot 6$ & $39 \cdot 3$ & $37 \cdot 2$ \\
\hline $\mathrm{AA}-\mathrm{N}(\mathrm{g} / \mathrm{kg} \mathrm{DM})$ & $3 \cdot 4$ & $3 \cdot 4$ & $10 \cdot 5$ & $32 \cdot 0$ & $27 \cdot 6$ \\
\hline $\mathrm{NDF}(\mathrm{g} / \mathrm{kg} \mathrm{DM})$ & 781 & 758 & 395 & 342 & 361 \\
\hline Hemicellulose (g/kg DM) & 289 & 263 & 171 & 161 & 176 \\
\hline Cellulose (g/kg DM) & 425 & 439 & 204 & 161 & 164 \\
\hline Lignin (g/kg DM) & 66 & 55 & 20 & 20 & 20 \\
\hline $\mathrm{AA}(\mathrm{mol} / \mathrm{kg} \mathrm{DM})$ & 0.19 & $0 \cdot 19$ & 0.59 & 1.90 & 1.61 \\
\hline \multicolumn{6}{|l|}{ AA profile $(\mathrm{mmol} / \mathrm{mol})$} \\
\hline Cystine & $10 \cdot 4$ & $11 \cdot 3$ & 11.5 & $4 \cdot 7$ & $8 \cdot 9$ \\
\hline Aspartic acid & $104 \cdot 9$ & $102 \cdot 1$ & 86.2 & 70.9 & 115.6 \\
\hline Methionine & 14.9 & $13 \cdot 3$ & $15 \cdot 5$ & $23 \cdot 6$ & $18 \cdot 4$ \\
\hline Threonine & $58 \cdot 3$ & $57 \cdot 1$ & 59.4 & $49 \cdot 0$ & $58 \cdot 1$ \\
\hline Serine & $74 \cdot 3$ & $72 \cdot 1$ & 76.9 & 73.6 & 68.9 \\
\hline Glutamic acid & $122 \cdot 1$ & $121 \cdot 6$ & 110.9 & $162 \cdot 6$ & $102 \cdot 7$ \\
\hline Proline & $57 \cdot 4$ & $60 \cdot 6$ & 59.9 & $104 \cdot 0$ & $54 \cdot 1$ \\
\hline Glycine & $103 \cdot 8$ & $108 \cdot 0$ & $89 \cdot 3$ & $46 \cdot 5$ & $80 \cdot 6$ \\
\hline Alanine & $96 \cdot 9$ & 97.6 & $80 \cdot 2$ & $52 \cdot 3$ & 69.8 \\
\hline Valine & $73 \cdot 1$ & $71 \cdot 5$ & 83.0 & $75 \cdot 9$ & 78.0 \\
\hline Isoleucine & $37 \cdot 2$ & $37 \cdot 7$ & $45 \cdot 6$ & $51 \cdot 2$ & $52 \cdot 0$ \\
\hline Leucine & $58 \cdot \overline{7}$ & $58 \cdot 8$ & $70 \cdot 1$ & $85-3$ & $85 \cdot 2$ \\
\hline Tyrosine & $15 \cdot 4$ & $15 \cdot 3$ & $35 \cdot 8$ & $34 \cdot 1$ & $34 \cdot 5$ \\
\hline Phenylalanine & $31 \cdot 8$ & 30.7 & $28 \cdot 6$ & $36 \cdot 8$ & $41 \cdot 3$ \\
\hline Lysine & $53 \cdot 4$ & $58 \cdot 4$ & $46 \cdot 1$ & $30 \cdot 2$ & $27 \cdot 7$ \\
\hline Histidine & $42 \cdot 3$ & 39.8 & 56.5 & $63 \cdot 2$ & 59.7 \\
\hline Arginine & $36 \cdot 0$ & $33 \cdot 1$ & $37 \cdot 0$ & $28 \cdot 9$ & $35 \cdot 1$ \\
\hline Tryptophan & $9 \cdot 1$ & 11.0 & $7 \cdot 6$ & $7 \cdot 2$ & $9 \cdot 4$ \\
\hline
\end{tabular}

SBP, sugarbeet pulp + minerals and vitamins; SBPC, SBP + casein; SBPP, SBP + potato protein; AA, amino acids; NDF, neutral-detergent fibre.

* For details of composition, see Table 1.

duodenum and ileum, which occurred on $4 \mathrm{~d}$ of the $10 \mathrm{~d}$ of faecal collection. Total DM withdrawn during duodenal and ileal sampling was approximately $15 \mathrm{~g} / \mathrm{d}$, which, averaged over the faecal collection period, would mean a maximal underestimation of faecal DM excretion of only $6 \mathrm{~g} / \mathrm{d}$. 


\section{Passage through the small intestine}

From day 1 to day 10 and again from day 16 to day 24 of each experimental period, $10 \mathrm{~g} \mathrm{Cr}-$ mordanted neutral-detergent fibre (NDF; Cr-NDF; average $\mathrm{Cr}$ concentration $53 \mathrm{~g} / \mathrm{kg}$ ) $/ \mathrm{d}$ and $3 \mathrm{~g}$ CoEDTA (average Co concentration $148 \mathrm{~g} / \mathrm{kg}$ ) $/ \mathrm{d}$, both prepared according to Udén et al. (1980), were introduced into the rumen at intervals of $6 \mathrm{~h}$ (starting at 06.00 hours) to get steady-state concentrations of $\mathrm{Cr}$ and $\mathrm{Co}$ in the rumen.

Two-hourly samples of approximately $20 \mathrm{~g}$ duodenal and ileal digesta were collected from days 6 to 9 and again from days 20 to 23 from 08.30 hours until 18.30 hours. These samples were freeze-dried, ground and pooled for each sheep, week and cannula and subsequently analysed for $\mathrm{DM}$, ash, $\mathrm{Co}, \mathrm{Cr}$, cell-wall composition, $\mathrm{N}$ and AA. As in the experiment described by Van Bruchem et al. (1993) with sheep fed on UWS and AWS, duodenal and ileal samples were representative in respect of fluid and particulate phases: the $\mathrm{Cr}$ : Co ratio introduced into the rumen was on average $1 \cdot 19$. In duodenal samples this ratio was 1.21 (SEM 0.018) and in ideal samples 1.24 (SEM 0.032), without significant differences between periods, animals and rations. Use of the double- or two-marker techniques to correct for non-representative sampling (Faichney, 1980), therefore, was not needed and daily duodenal or ileal flows of nutrients were calculated from the concentration of that nutrient: the concentration of $\mathrm{Co}$ or $\mathrm{Cr}$ in duodenal or ileal digesta multiplied by the daily $\mathrm{Cr}$ or $\mathrm{Co}$ flow. Flows presented or used for further calculations were averages of estimates based on $\mathrm{Co}$ and $\mathrm{Cr}$. Correction of the ileal flow for withdrawal of digesta from the duodenum was not required because the concentration of a nutrient relative to the concentration of markers is not affected by duodenal sampling.

The duodenal flows of microbes were estimated by the following methods:

(1) Diaminopimelic acid (DAPA) method, based on the daily DAPA flow in the duodenum and the DAPA: $\mathrm{N}$ ratio in isolated rumen bacteria,

(2) AA profile method, based on the AA profiles of ingested protein, bovine pepsinogen (Siddons et al. 1982), microbial protein and duodenal digesta. Dietary, pepsinogen and microbial AA were mixed by an iterative procedure in such proportions that the computed AA profiles best matched the actual AA profiles of duodenal protein. This was tested by minimizing the objective function:

$$
\sum_{A A-1}^{A A=16}\left(1-\mathrm{AA}_{\text {computed }} / \mathrm{AA}_{\text {actual }}\right)^{2} .
$$

This procedure was done for sixteen AA, omitting cystine (because of the high analytical variation) and tryptophan (the tryptophan concentration in pepsinogen was unknown).

(3) Purine derivatives method, based on excretion of purine derivatives in the urine measured according to the method described by Chen et al. $(1990 \mathrm{~b})$. From the daily urinary excretion of purine derivatives the corresponding amount of microbial purines absorbed by the animal was estimated based on the model described by Chen et al. $(1990 \mathrm{a})$. The duodenal flow of microbial $\mathrm{N}$ was then calculated from the absorbed quantity of microbial purines by assuming a digestibility of microbial purines of 0.83 and a purine- $\mathrm{N}$ : total microbial-N value of $0 \cdot 116$ (Chen et al. 1991).

\section{Rumen fluid, rumen fermentation and rumen passage}

The steady-state concentration of Co in rumen fluid was measured in samples of $50 \mathrm{ml}$ taken from days 6 to 9 and again from days 20 to 23 at 08.00 and 10.00 hours. The rumen fluid volume was estimated from the Co concentration in the rumen fluid samples by the following equation, applying to a steady-state situation in the rumen: 


$$
\text { rumen fluid volume (litres) }=\frac{\text { daily dosage of } \mathrm{Co}(\mathrm{mg} / \mathrm{d})}{\text { concentration of } \operatorname{Co}(\mathrm{mg} / 1) \times k_{l}(/ \mathrm{d})} \text {, }
$$

where $k_{l}$ is the fractional rate of passage of Co.

Rumen samples for determination of $\mathrm{pH}$ (immediately after sampling) and concentration of VFA, $\mathrm{NH}_{3}-\mathrm{N}$ and Co were taken two-hourly on day 10 and again on day 24 starting at 08.00 hours, $2 \mathrm{~h}$ after the last dosing of $\mathrm{Cr}-\mathrm{NDF}$ and CoEDTA, to 20.00 hours. One additional sample was taken on days 11 and 25 . Co was also determined in rumen fluid samples taken at 10.00 and 12.00 hours on days 11 and 25 . Faecal samples (total collection) for analysis of $\mathrm{Cr}$ concentration were collected over the following time intervals after the last dosing of Cr-NDF on days 10 and 24: 24-28, 28-32, 32-36, 36-40, 48-52, 52-56, $56-60,60-64,72-76,76-80,80-84,84-88,96-104,104-112,112-120,120-128$ and $128-136 \mathrm{~h}$. The fractional rate of passage of rumen fluid from the rumen $\left(k_{l}\right.$; based on rumen Co concentration) and the fractional rate of passage of the particulate-phase marker $\mathrm{Cr}-\mathrm{NDF}\left(k_{p}\right.$; based on the descending part of the faecal excretion curve of $\mathrm{Cr}$ ) were estimated according to Grovum \& Williams (1973).

\section{Rumen microbes}

From rumen fluid samples of $50 \mathrm{ml}$, taken at the same moment as those for estimation of steady-state Co concentration in rumen fluid, rumen microbes were isolated as described by Oosting et al. (1993 b). After freeze-drying, grinding through a $1 \mathrm{~mm}$ sieve and pooling for each animal and week, samples were stored pending $\mathrm{N}$ and AA analyses. In rumen-fluid samples taken for estimation of the steady-state Co concentration, the concentration of DAPA was also determined.

\section{Dacron bag analysis}

For the straw and supplements in the present experiment, the disappearance of $\mathrm{N}$ from small Dacron bags introduced into the duodenal cannula was measured in cattle. Feed samples were all ground through a $1 \mathrm{~mm}$ sieve and incubated in Dacron bags (size $70 \times 120 \mathrm{~mm}$, pore size $41 \mu \mathrm{m} \times 41 \mu \mathrm{m}$ ) for $12 \mathrm{~h}$ in the rumen of two steers fed on UWS. Straw was also incubated for 24 and $48 \mathrm{~h}$. After collection and washing of the bags, the residue was dried at $70^{\circ}$ for $48 \mathrm{~h}$ and pooled for each feed. A sub-sample was taken for DM and $\mathrm{N}$ analysis and eighteen subsamples of approximately $0.5 \mathrm{~g}$ of each feed were weighed into small Dacron bags (size $30 \times 60 \mathrm{~mm}$, pore size $41 \mu \mathrm{m} \times 41 \mu \mathrm{m}$ ). These samples were incubated in pepsin- $\mathrm{HCl}(1 \mathrm{~g}$ pepsin $/ 11 \mathrm{M}-\mathrm{HCl})$ at $39^{\circ}$ for $1 \mathrm{~h}$ and subsequently introduced into the distal duodenum of six cows in triplicate per feed per cow. These cows were fed on a ration consisting of $(\mathrm{g} / \mathrm{kg})$ : dried grass 400 and concentrates 600 . After collection of the bags voided with the faeces, washing in tap-water and drying at $70^{\circ}$ for $48 \mathrm{~h}$, the residues were pooled for each feed and analysed for DM and $\mathbf{N}$.

\section{Chemical analysis}

$\mathrm{DM}$, ash, $\mathrm{N}, \mathrm{NH}_{3}-\mathrm{N}$ in rumen fluid, $\mathrm{NDF}$, acid-detergent fibre (ADF), acid-detergent lignin (ADL), Co and $\mathrm{Cr}$ and VFA were all determined by the methods described by Oosting et al. (1994). Hemicellulose was calculated as NDF-ADF, and cellulose as ADF-ADL. AA including DAPA were determined as described by Oosting et al. (1993 b). Tryptophan was analysed after alkaline-hydrolysis. A sample containing 25-50 mg protein was mixed in a test-tube with $16 \mathrm{ml} 4 \mathrm{M}-\mathrm{LiOH}$. After cooling in ice, the tubes were evacuated and subsequently put into an oven at $120^{\circ}$. After boiling for $16 \mathrm{~h}$ the $\mathrm{pH}$ was reduced to 4.5 by adding $\mathrm{HCl}(12 \mathrm{M})$ with continuous stirring. Then the sample was centrifuged at $550 \mathrm{~g}$ and the supernatant fraction quantitatively transferred into a $50 \mathrm{ml}$ volumetric flask and filled to the mark. Of this solution, $5 \mathrm{ml}$ was mixed with a phosphate 
buffer $\left(11.4 \mathrm{~g} \mathrm{~K}_{2} \mathrm{HPO}_{4} \cdot 3 \mathrm{H}_{2} \mathrm{O}\right.$ and $6.8 \mathrm{~g} \mathrm{KH}_{2} \mathrm{PO}_{4} / 1$ water and an internal standard (5-methyl-DL-tryptophan; $1 \mathrm{mmol} / \mathrm{l}$; Sigma). After centrifugation at $70000 \mathrm{~g}$, the supernatant fraction was analysed by HPLC (isocratic system; eluent $13.6 \mathrm{~g}$ sodiumacetate $3 \mathrm{H}_{2} \mathrm{O}$ and $5.7 \mathrm{ml}$ acetic acid in 2 litres water to which $353 \mathrm{ml}$ methanol was added; $100 \mathrm{~mm}$ Lichiosorb RP-18 column; u.v. detection at $280 \mathrm{~nm}$ ).

\section{Calculations and statistics}

The true digestion of individual and total AA (TAA), AA-N, N and non-protein-N (NPN) in the small intestine or over the whole digestive tract (only for $\mathrm{N}$ ) was estimated by Lucas equations (Van Soest, 1982) of the following general form:

$$
\mathrm{DX}=a+b \mathrm{X},
$$

where $\mathrm{X}$ and $\mathrm{DX}$ represent the concentrations of a nutrient and the disappeared nutrient respectively (in the duodenal flow of non-protein DM (NPDM) for estimation of the smallintestinal true digestion and in organic matter intake for estimation of the whole-tract true digestion), $a$ is the endogenous loss of the nutrient per $100 \mathrm{~g}$ duodenal NPDM flow or organic matter intake and $b$ is the true digestion as a proportion of intake (for whole-tract digestion of $\mathrm{N}$ ) and of duodenal influx (for true small-intestinal digestion of nutrients).

The equation for estimation of the small-intestine true digestion as given previously was derived from the equation used by Van Bruchem et al. (1989). The latter equation to estimate endogenous AA output and true AA digestion in the small intestine had the following form:

$$
\text { ileal AA flow } \left.=a+b_{1} \text { (duodenal AA flow }\right)+b_{2} \text { (duodenal NPDM flow). }
$$

However, in the Van Bruchem et al. (1989) results and in the present experiment, the intercept, $a$, in the equation given previously was never significantly different from zero, either for individual AA or for TAA. It, therefore, can be omitted. AA disappearance in the small intestine (D) is then given by:

$$
\begin{aligned}
\mathrm{D} & =\text { duodenal AA flow-ileal AA flow, } \\
& =\left(1-b_{1}\right) \text { (duodenal AA flow) }-b_{2} \text { (duodenal NPDM flow). }
\end{aligned}
$$

DX, which is AA disappearance as a function of duodenal NPDM, is defined as

$$
\begin{aligned}
\mathrm{DX} & =\mathrm{D} / \mathrm{NPDM}, \\
& =\left(\left(1-b_{1}\right) \text { (duodenal AA flow) }-b_{2} \text { (duodenal NPDM flow) }\right) / \text { duodenal NPDM flow, } \\
& =a+b \mathrm{X},
\end{aligned}
$$

where $\mathrm{X}$ is duodenal AA concentration in duodenal NPDM, $a=-b_{2}$ and $b=1-b_{1}$.

Means for each animal within period (average of two repeated measurements) were statistically analysed by the program DBSTAT (Brouwer, 1989) with the model:

$$
Y_{i j k l}=\mu+\text { period }_{i}+\text { animal }_{j}+\text { ration }_{k}+\text { error }_{i j k l},
$$

with $n$ 16. Differences between ration means were compared by Student's $t$ test (Snedecor \& Cochran, 1967), only if the ration effect was significant.

\section{RESULTS}

Intake and digestion

$\mathrm{NH}_{3}$ treatment increased intake and whole-tract and rumen digestion of all dietary constituents significantly (Table 3 ). Supplementation of AWS with potato protein increased total organic matter intake $(P<0.05)$, whereas supplementation with casein 
Table 3. Intake and digestion of organic matter and fibre fractions and average weight of sheep given rations containing untreated wheat straw (UWS) and ammoniated wheat straw alone $(A W S)$ and with casein $(A W S C)$ or potato-protein $(A W S P)$ supplements*

\begin{tabular}{|c|c|c|c|c|c|}
\hline Ration... & UWS & AWS & AWSC & AWSP & SEM \\
\hline \multicolumn{6}{|l|}{ Organic matter } \\
\hline \multicolumn{6}{|l|}{ Intake: $\mathrm{g} / \mathrm{kg} \mathrm{W}^{0.75}$ per $\mathrm{d}$} \\
\hline Whole ration & $41-2^{\mathrm{a}}$ & $49 \cdot 2^{b}$ & $49 \cdot 4^{b}$ & $56 \cdot 2^{\mathrm{c}}$ & $1 \cdot 32$ \\
\hline Straw & $24 \cdot 4^{a}$ & $32 \cdot 6^{\mathrm{bc}}$ & $29 \cdot 4^{b}$ & $35 \cdot 7^{\mathrm{c}}$ & $1 \cdot 22$ \\
\hline \multicolumn{6}{|l|}{$\mathrm{g} /$ animal per $\mathrm{d}$} \\
\hline Whole ration & $872^{\mathrm{a}}$ & $1070^{b}$ & $1090^{b}$ & $1260^{\mathrm{c}}$ & 33.5 \\
\hline Straw & $516^{\mathrm{a}}$ & $709^{\mathrm{be}}$ & $649^{b}$ & $800^{c}$ & $30 \cdot 5$ \\
\hline \multicolumn{6}{|l|}{ Digestion: $\mathrm{g} / \mathrm{kg}$ ingested } \\
\hline Whole tract & $619^{a}$ & $629^{a b}$ & $628^{\mathrm{ab}}$ & $643^{b}$ & $4 \cdot 7$ \\
\hline \multicolumn{6}{|l|}{$\mathrm{g} / \mathrm{kg}$ digested } \\
\hline Rumen & $775^{\mathrm{b}}$ & $773^{b}$ & $703^{\mathrm{ab}}$ & $663^{\mathrm{a}}$ & $26 \cdot 2$ \\
\hline Small intestine & 123 & 124 & 175 & 205 & $28 \cdot 0$ \\
\hline Large intestine & 102 & 104 & 123 & 132 & $19 \cdot 0$ \\
\hline $\begin{array}{l}\text { Digestible organic matter intake } \\
\left(\mathrm{g} / \mathrm{kg} \mathrm{W}^{0.75} \text { per } \mathrm{d}\right)\end{array}$ & $25 \cdot 5^{a}$ & $30 \cdot 9^{b}$ & $31 \cdot 0^{\mathrm{b}}$ & $35 \cdot 9^{\mathrm{c}}$ & $0 \cdot 90$ \\
\hline \multicolumn{6}{|l|}{ Neutral-detergent fibre } \\
\hline Intake (g/kg W W $^{075}$ per d) & $28 \cdot 1^{a}$ & $34 \cdot 4^{\mathrm{bc}}$ & $32 \cdot 2^{\mathrm{b}}$ & $37 \cdot 6^{c}$ & $1 \cdot 02$ \\
\hline \multicolumn{6}{|l|}{ Digestion: ( $\mathrm{g} / \mathrm{kg}$ ingested $)$} \\
\hline Whole tract & $597^{a}$ & $647^{\mathrm{e}}$ & $622^{\mathrm{b}}$ & $642^{\mathrm{e}}$ & $6 \cdot 0$ \\
\hline Rumen & $555^{\mathrm{a}}$ & $602^{b}$ & $547^{\mathrm{a}}$ & $564^{\mathrm{ab}}$ & $12 \cdot 3$ \\
\hline \multicolumn{6}{|l|}{$\mathrm{g} / \mathrm{kg}$ digested } \\
\hline Rumen & 933 & 935 & 880 & 883 & $23 \cdot 5$ \\
\hline \multicolumn{6}{|l|}{ Hemicellulose } \\
\hline Intake $\left(\mathrm{g} / \mathrm{kg} \mathrm{W}^{0.75}\right.$ per d) & $10 \cdot 9^{\mathrm{a}}$ & $12 \cdot 6^{\mathrm{bc}}$ & $12 \cdot 3^{b}$ & $14 \cdot 2^{\mathrm{c}}$ & 0.43 \\
\hline \multicolumn{6}{|l|}{ Digestion: $\mathrm{g} / \mathrm{kg}$ ingested } \\
\hline Whole tract & $639^{a}$ & $699^{b}$ & $696^{b}$ & $712^{\mathrm{b}}$ & $7 \cdot 3$ \\
\hline Rumen & $564^{a}$ & $614^{b}$ & $565^{\mathrm{a}}$ & $592^{\mathrm{ab}}$ & $9 \cdot 6$ \\
\hline \multicolumn{6}{|l|}{$\mathrm{g} / \mathrm{kg}$ digested } \\
\hline Rumen & $883^{b}$ & $878^{b}$ & $813^{a}$ & $830^{\mathrm{ah}}$ & $18 \cdot 9$ \\
\hline \multicolumn{6}{|l|}{ Cellulose } \\
\hline Intake $\left(\mathrm{g} / \mathrm{kg} \mathbf{W}^{0.75}\right.$ per $\left.\mathrm{d}\right)$ & $15 \cdot 0^{\mathrm{a}}$ & $19 \cdot 4^{\mathrm{bc}}$ & $18 \cdot 1^{\mathrm{b}}$ & $20 \cdot 8^{\mathrm{e}}$ & 0.51 \\
\hline \multicolumn{6}{|l|}{ Digestion: $\mathrm{g} / \mathrm{kg}$ ingested } \\
\hline Whole tract & $659^{a}$ & $699^{b}$ & $666^{\mathrm{a}}$ & $674^{a}$ & $7 \cdot 4$ \\
\hline Rumen & $604^{a}$ & $651^{\mathrm{b}}$ & $600^{a}$ & $604^{a}$ & $10 \cdot 3$ \\
\hline \multicolumn{6}{|l|}{$\mathrm{g} / \mathrm{kg}$ digested } \\
\hline Rumen & 918 & 930 & 900 & 898 & $26 \cdot 1$ \\
\hline W (average; kg) & $58 \cdot 8^{\mathrm{a}}$ & $60 \cdot 4^{\mathrm{ab}}$ & $61 \cdot 3^{\mathrm{ab}}$ & $63 \cdot 0^{\mathrm{b}}$ & $1 \cdot 28$ \\
\hline
\end{tabular}

a.b.c Values in a row with different superscript letters were significantly different $(P<0.05)$.

$\mathrm{W}$, live weight.

* For details of composition, see Tables 1 and 2.

did not affect organic matter intake. The differences between rations with regard to intake of cell-wall components reflect differences in straw intake, since intake of cell-wall components from the supplements was similar for all rations. Intakes of NDF, hemicellullose, cellulose and lignin from the supplements were $7.5,3.4,3.7$ and $0.4 \mathrm{~g} / \mathrm{kg} \mathrm{W}^{0.75}$ per $\mathrm{d}$ respectively.

Compared with AWS, AWSC and AWSP had significantly lower whole-tract and rumen digestion of cellulose. Rumen digestion of hemicellulose was, in contrast to its whole-tract digestion, significantly lower for AWSC than for AWS. 
Table 4. Rumen fluid volume, rumen passage rates and rumen fermentation characteristics of sheep given rations containing untreated wheat straw (UWS) and ammoniated wheat straw alone $(A W S)$ or with casein $(A W S C)$ or potato-protein $(A W S P)$ supplements*†

\begin{tabular}{|c|c|c|c|c|c|}
\hline Ration... & UWS & AWS & AWSC & AWSP & SEM \\
\hline Rumen volume (litres) & $6 \cdot 0^{\mathrm{a}}$ & $7 \cdot 5^{\mathrm{bc}}$ & $6 \cdot 6^{\mathrm{ab}}$ & $8 \cdot 9^{\circ}$ & $0 \cdot 43$ \\
\hline $\begin{array}{l}k_{l}(\% \text { per } \mathrm{h}) \\
k_{p}(\% \text { per } \mathrm{h})\end{array}$ & $\begin{array}{l}7 \cdot 5 \\
3 \cdot 5\end{array}$ & $\begin{array}{l}8 \cdot 1 \\
3 \cdot 8\end{array}$ & $\begin{array}{l}8 \cdot 2 \\
4 \cdot 1\end{array}$ & $\begin{array}{l}7 \cdot 4 \\
3 \cdot 7\end{array}$ & $\begin{array}{l}0 \cdot 32 \\
0 \cdot 17\end{array}$ \\
\hline VFA concentration $(\mathrm{mmol} / \mathrm{l})$ & $101 \cdot 4^{a}$ & $109 \cdot 8^{\mathrm{ab}}$ & $117 \cdot 9^{\mathrm{b}}$ & $120 \cdot 6^{\mathrm{b}}$ & $4 \cdot 10$ \\
\hline \multicolumn{6}{|c|}{ Molar proportions of VFA (mmol/mol) } \\
\hline Acetate & $710^{\mathrm{a}}$ & $729^{b}$ & $700^{\mathrm{a}}$ & $709^{a}$ & $3 \cdot 2$ \\
\hline Propionate & $188^{\mathrm{b}}$ & $177^{\mathrm{a}}$ & $194^{\mathrm{b}}$ & $188^{\mathrm{b}}$ & $3 \cdot 5$ \\
\hline Butyrate & 95 & 90 & 89 & 93 & $2 \cdot 9$ \\
\hline Isovalerate & $3^{\mathrm{a}}$ & $1^{\mathrm{a}}$ & $8^{b}$ & $5^{\mathrm{ab}}$ & $1 \cdot 5$ \\
\hline Valerate & $3^{a}$ & $3^{\mathrm{a}}$ & $11^{\circ}$ & $5^{\mathrm{h}}$ & $0 \cdot 6$ \\
\hline $\mathrm{pH}$ & $6 \cdot 3$ & 6.2 & $6 \cdot 2$ & 62 & 0.05 \\
\hline $\mathrm{NH}_{3}-\mathrm{N}$ concentration $(\mathrm{mg} / \mathrm{l})$ & $101 \cdot 4^{\mathrm{a}}$ & $109 \cdot 8^{\mathrm{ab}}$ & $117 \cdot 9^{b}$ & $120 \cdot 6^{b}$ & $4 \cdot 10$ \\
\hline
\end{tabular}

a.b.e Values in a row with different superscript letters were significantly different $(P<0.05)$.

$k_{l}$, fractional rate of passage of $\mathrm{Co} ; k_{p}$, fractional rate of passage of particulate-phase marker; VFA, volatile fatty acids.

* For details of composition, see Tables 1 and 2.

$\dagger$ For details of procedures, see pp. 348-351.

The small-intestinal digestion of cell-wall components did not differ significantly from zero and is not given in Table 3. No differences in the contribution of the rumen to wholetract digestion were observed between UWS and AWS. The proportion of digestion occurring in the rumen was lower for AWSC and AWSP than for AWS (significantly for hemicellulose in the case of AWSC and for organic matter in the case of AWSP).

Duodenal flows of NDF were 264, 295, 326 and 369 (SEM 18.4) g/d for UWS, AWS, AWSC and AWSP respectively, being significantly higher for AWSP than for UWS and AWS. The daily quantities of NDF digested in the rumen were 333, 451, 392 and 473 (SEM 12.6) g for UWS, AWS, AWSC and AWSP respectively, being lowest for UWS $(P<$ $0.05)$ and significantly lower for AWSC than for the other two AWS-based rations.

\section{Rumen fluid volume, rumen passage and rumen fermentation}

Rumen fluid volume was significantly higher for AWSP than for AWSC (Table 4). Ammoniation of wheat straw significantly increased rumen fluid volume. Regression of rumen fluid volume (litres) v. NDF intake $(\mathrm{g} / \mathrm{d})$ with inclusion of the animal effect as a factor in the regression model yielded the following equation (the intercept is the average over animals, with the SE of the estimate):

rumen fluid volume $=-1 \cdot 2(\mathrm{SE} 1 \cdot 29)+0 \cdot 012(\mathrm{SE} 0 \cdot 0017)$

$\times$ NDF intake $\left(r^{2} 0 \cdot 876, n 16\right.$, residual SD $\left.0 \cdot 73\right)$.

The data (uncorrected) are plotted in Fig. 1.

No significant differences were observed between rations with regard to $k_{l}$ and $k_{p}$. The $k_{l}$ and $k_{p}$ were significantly correlated $(r 0.854, n 16, P<0.001)$. The $\mathrm{pH}$ and the VFA and $\mathrm{NH}_{3}-\mathrm{N}$ concentrations in the rumen fluid were not significantly different between UWS and AWS and between AWS and AWSC or AWSP (Table 4). Molar proportions of individual VFA differed only slightly between rations. Only traces of isobutyrate were found (not included in Table 4). 


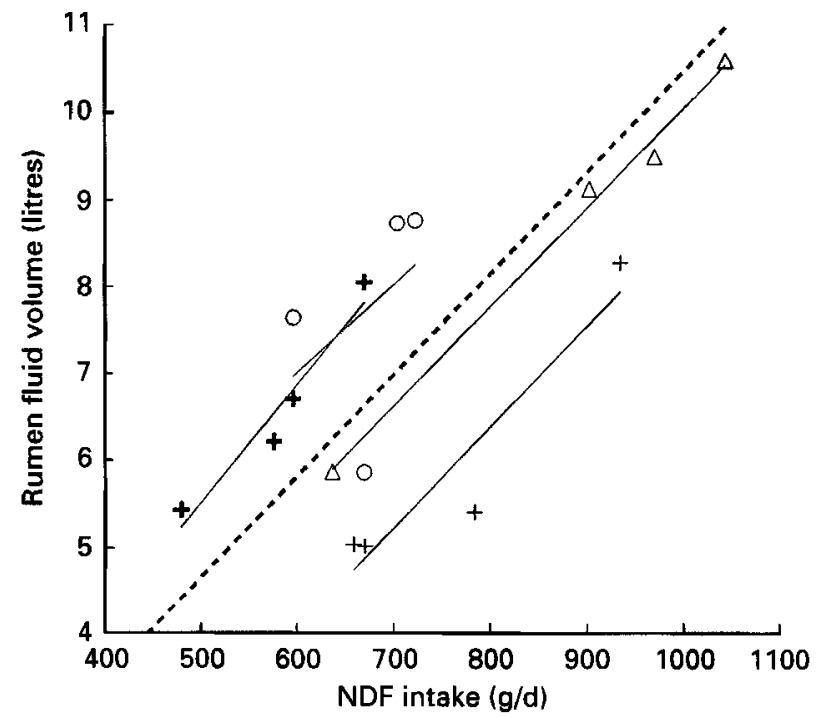

Fig. 1. Relationship between rumen fluid volume and neutral-detergent fibre (NDF) intake for four sheep given experimental rations containing untreated wheat straw or ammoniated wheat straw alone or with casein or potatoprotein supplements. For details of rations and procedures, see Tables 1 and 2 and pp. 348-351. (+), Sheep 1; $(\triangle)$, sheep $2 ;(O)$, sheep $3 ;(+)$, sheep 4 . Values given for each sheep represent each of the experimental rations.

Table 5. Disappearance $(D)$ of $N(\mathrm{~g} / \mathrm{kg})$ from Dacron bags in cattle for untreated wheat straw (UWS), ammoniated wheat straw $(A W S)$ and sugarbeet pulp + minerals and vitamins $(S B P)$, $S B P+$ casein $(S B P C)$ and $S B P+$ potato protein $(S B P P)^{*+}$

(Values are from analysis in one pooled sample within feed and duration of rumen incubation)

\begin{tabular}{|c|c|c|c|}
\hline & $\mathrm{D}_{\text {Rumen }}$ & $\mathrm{D}_{\text {Intestines }} \ddagger$ & $\mathrm{D}_{\text {whole-tract }} \S$ \\
\hline \multicolumn{4}{|l|}{ UWS } \\
\hline $12 \mathrm{~h} \|$ & 221 & 652 & 729 \\
\hline $24 \mathrm{~h}$ & 147 & 715 & 756 \\
\hline $48 \mathrm{~h}$ & 86 & 774 & 794 \\
\hline \multicolumn{4}{|l|}{ AWS } \\
\hline $12 \mathrm{~h}$ & 531 & 607 & 815 \\
\hline $24 \mathrm{~h}$ & 549 & 672 & 852 \\
\hline $48 \mathrm{~h}$ & 522 & 750 & 880 \\
\hline \multicolumn{4}{|l|}{ SBP } \\
\hline $12 \mathrm{~h}$ & 452 & 904 & 947 \\
\hline \multicolumn{4}{|l|}{ SBPC } \\
\hline $12 \mathrm{~h}$ & 856 & 966 & 995 \\
\hline \multicolumn{4}{|l|}{ SBPP } \\
\hline $12 \mathrm{~h}$ & 447 & 974 & 985 \\
\hline
\end{tabular}

* For details of composition, see Tables 1 and 2.

$\dagger$ For details of procedures, see p. 351-352.

¥ Incubation of residue after rumen incubation in pepsin $(E C 3.4 .23 .1)$-HCl followed by introduction into the duodenum and collection in faeces.

$\S N$ disappearance from rumen and intestines $\left(=D_{\text {Rumen }}+\left(1000-D_{\text {Rumen }}\right) \times D_{\text {Intestines }} / 1000\right)$.

|| Duration of rumen incubation. 
Table 6. Molar proportions of amino acids (AA; mmol/mol total AA) of dietary intake, bovine pepsinogen, rumen microbes and duodenal digesta and percentage contribution of $A A$ of microbial, feed and endogenous origin to total duodenal $A A$ of sheep given rations containing untreated wheat straw (UWS) and ammoniated wheat straw alone $(A W S)$ or with casein (AWSC) or potato-protein (AWSP) supplements* ${ }^{*}$

\begin{tabular}{|c|c|c|c|c|c|c|c|c|c|c|}
\hline & \multicolumn{4}{|c|}{ Dietary intake } & \multirow[b]{2}{*}{ Endogenous } & \multirow[b]{2}{*}{$\begin{array}{l}\text { Rumen } \\
\text { microbes }\end{array}$} & \multicolumn{4}{|c|}{ Duodenal digesta } \\
\hline & $\begin{array}{c}\text { UWS or } \\
\text { AWS }\end{array}$ & AWSC & AWSP & SEM & & & $\begin{array}{c}\text { UWS or } \\
\text { AWS }\end{array}$ & AWSC & AWSP & SEM \\
\hline Cys & $11 \cdot 2^{c}$ & $5 \cdot 5^{\mathrm{a}}$ & $9 \cdot 2^{\mathrm{b}}$ & 0.40 & na & $7 \cdot 6$ & $12 \cdot 6^{\mathrm{b}}$ & $12 \cdot 7^{\mathrm{b}}$ & $10 \cdot 9^{a}$ & 0.29 \\
\hline Asp & $92 \cdot 2^{\mathrm{b}}$ & $75 \cdot 0^{\mathrm{a}}$ & $113 \cdot 4^{\mathrm{c}}$ & 0.29 & $115 \cdot 0$ & $114 \cdot 3$ & $106 \cdot 7^{\mathrm{a}}$ & $105 \cdot 6^{\mathrm{u}}$ & $109 \cdot 4^{b}$ & 0.72 \\
\hline Met & $149^{a}$ & $22 \cdot 3^{c}$ & $17 \cdot 5^{\mathrm{b}}$ & 0.35 & $10-8$ & $19 \cdot 4$ & $15 \cdot 9^{\mathrm{a}}$ & $17 \cdot 1^{\mathrm{b}}$ & $16 \cdot 8^{b}$ & 0.23 \\
\hline Thr & $58 \cdot 8^{\mathrm{b}}$ & $50 \cdot 1^{a}$ & $57.9^{\mathrm{b}}$ & 0.23 & $76 \cdot 3$ & $62 \cdot 6$ & $61 \cdot 7^{b}$ & $61 \cdot 1^{\mathrm{a}}$ & $61 \cdot 7^{b}$ & $0 \cdot 17$ \\
\hline Ser & $75 \cdot 6^{\mathrm{c}}$ & $73 \cdot 5^{b}$ & $69 \cdot 5^{a}$ & 0.35 & $143 \cdot 2$ & $59 \cdot 1$ & $63 \cdot 8^{b}$ & $62 \cdot 6^{\mathrm{a}}$ & $65 \cdot 1^{\circ}$ & 0.32 \\
\hline Glu & $114 \cdot 8^{\mathfrak{b}}$ & $157 \cdot 2^{\mathrm{c}}$ & $105 \cdot 9^{\mathrm{a}}$ & 0.66 & $92 \cdot 2$ & $104: 2$ & $106 \cdot 3^{b}$ & $107 \cdot 9^{b}$ & $100 \cdot 1^{\mathrm{a}}$ & 1.07 \\
\hline Pro & $59 \cdot 7^{\mathrm{b}}$ & $98 \cdot 4^{\circ}$ & $55 \cdot 4^{\mathrm{a}}$ & $1 \cdot 21$ & $44 \cdot 3$ & $34 \cdot 9$ & $43 \cdot 6^{a}$ & $46 \cdot 1^{b}$ & $48 \cdot 5^{\mathrm{c}}$ & 0.49 \\
\hline Gly & $94 \cdot 2^{c}$ & $54 \cdot 6^{\mathrm{a}}$ & $88 \cdot 3^{b}$ & 0.46 & $99 \cdot 4$ & $92 \cdot 4$ & $93 \cdot 3^{b}$ & $92 \cdot 1^{\mathrm{b}}$ & $90 \cdot 3^{a}$ & 0.35 \\
\hline Ala & $86 \cdot 2^{c}$ & $58 \cdot 2^{a}$ & $74 \cdot 5^{b}$ & 0.61 & $46 \cdot 0$ & $103 \cdot 1$ & $96 \cdot 8^{b}$ & $96 \cdot 1^{b}$ & $87 \cdot 4^{a}$ & 0.52 \\
\hline Val & $79 \cdot 3^{b}$ & $76 \cdot 5^{\mathrm{a}}$ & $76 \cdot 9^{a}$ & 0.55 & $71 \cdot 2$ & $71 \cdot 6$ & $71 \cdot 7$ & $71 \cdot 8$ & $73 \cdot 5$ & 0.55 \\
\hline Ile & $42 \cdot 7^{a}$ & $49 \cdot 4^{b}$ & $49 \cdot 6^{\mathrm{b}}$ & 0.17 & $90 \cdot 1$ & $57 \cdot 5$ & $55 \cdot 0^{8}$ & $55 \cdot 2^{\mathrm{a}}$ & $58 \cdot 6^{b}$ & $0 \cdot 35$ \\
\hline Leu & $66 \cdot 2^{\mathrm{a}}$ & $81 \cdot 8^{\circ}$ & $80 \cdot 6^{b}$ & 0.32 & $72 \cdot 0$ & $70 \cdot 6$ & $73 \cdot 4^{\mathrm{a}}$ & $73 \cdot 6^{a}$ & $80 \cdot 5^{b}$ & 0.64 \\
\hline Tyr & $28 \cdot 7^{\mathrm{a}}$ & $31 \cdot 6^{\mathrm{b}}$ & $31 \cdot 2^{b}$ & 0.23 & $50 \cdot 8$ & 33.8 & $28 \cdot 6^{\mathrm{a}}$ & $28 \cdot 6^{\mathrm{a}}$ & $30 \cdot 5^{\mathrm{b}}$ & 0.20 \\
\hline Phe & $29 \cdot 4^{\mathrm{a}}$ & $36 \cdot 0^{\mathrm{b}}$ & $39 \cdot 5^{\mathrm{c}}$ & 0.81 & $42 \cdot 9$ & $37 \cdot 6$ & $37 \cdot 1^{\mathrm{a}}$ & $37 \cdot 1^{\mathrm{a}}$ & $40 \cdot 6^{b}$ & 0.38 \\
\hline His & $49 \cdot 5^{b}$ & $33 \cdot 9^{\mathrm{a}}$ & $32 \cdot 9^{\mathrm{a}}$ & $1 \cdot 10$ & 5.6 & $26 \cdot 5$ & $31 \cdot 5^{b}$ & $31 \cdot 5^{b}$ & $29 \cdot 4^{\mathrm{a}}$ & 0.52 \\
\hline Lys & $51 \cdot 2^{\mathrm{a}}$ & $60 \cdot 1^{c}$ & $56 \cdot 3^{b}$ & 0.32 & $23 \cdot 0$ & $65 \cdot 5$ & $63 \cdot 3^{b}$ & $63 \cdot 0^{\mathrm{b}}$ & $61.9^{\mathrm{a}}$ & 0.26 \\
\hline Arg & $36 \cdot 1^{b}$ & $29 \cdot 4^{a}$ & $34 \cdot 7^{b}$ & 0.40 & $17 \cdot 7$ & $31 \cdot 3$ & $30 \cdot 9$ & $30 \cdot 1$ & $31 \cdot 2$ & 0.43 \\
\hline Try & $8 \cdot 5^{\mathrm{b}}$ & $7 \cdot 7^{a}$ & $9 \cdot 7^{\mathrm{c}}$ & 0.09 & na & $8 \cdot 1$ & $8 \cdot 2$ & $8 \cdot 1$ & $8 \cdot 2$ & $0 \cdot 12$ \\
\hline \multicolumn{11}{|c|}{$\begin{array}{r}\text { Composition of } \\
\text { duodenal AA } \S\end{array}$} \\
\hline Microbial & & & & & & & $69 \cdot 6^{\mathrm{h}}$ & $82 \cdot 1^{c}$ & $53 \cdot 0^{\mathrm{a}}$ & 1.80 \\
\hline Feed & & & & & & & $28 \cdot 1^{\mathrm{b}}$ & $16 \cdot 9^{\mathrm{a}}$ & $44 \cdot 6^{c}$ & 1.68 \\
\hline Endogenous & & & & & & & $2 \cdot 2$ & $1 \cdot 1$ & $2 \cdot 2$ & 0.91 \\
\hline
\end{tabular}

$\mathbf{a}, \mathbf{b}, \mathbf{c}$ Means in a row with different superscript letters were significantly different $(P<0.05)$.

na, Not available.

* For details of composition, see Tables 1 and 2.

$\dagger$ For details of procedures, see pp. 348-351.

$\ddagger$ Composition of bovine pepsinogen adapted from Siddons et al. (1982).

$\S$ Percentage of duodenal AA flow.

\section{$N$ disappearance from Dacron bags in cattle}

Apparent $\mathrm{N}$ disappearance in the rumen of steers decreased with incubation time for UWS (Table 5), which should be attributed to contamination with microbial N. For UWS, values for DM disappearance from Dacron bags incubated in the rumen 227,318 and $488 \mathrm{~g} / \mathrm{kg}$ for incubation periods of 12,24 and $48 \mathrm{~h}$ respectively. For AWS, also, contamination with microbial $\mathrm{N}$ was likely, since $\mathrm{N}$ disappearance from Dacron bags incubated in the rumen did not change with incubation period, while DM disappearance values were 190, 397 and $615 \mathrm{~g} / \mathrm{kg}$ after rumen incubation for 12,24 and $48 \mathrm{~h}$ respectively. For both UWS and AWS, post-rumen $\mathrm{N}$ disappearance from Dacron bags (pepsin (EC 3.4.23.1)-HCl incubation of residue after rumen incubation followed by introduction into the duodenum of cattle) and whole-tract $\mathrm{N}$ disappearance increased with increasing duration of pre-incubation in the rumen.

Rumen $\mathrm{N}$ disappearance from Dacron bags was higher for SBPC than for SBP and 
Table 7. Composition of rumen microbes, the size of the rumen microbial pool associated with the rumen fluid and the efficiency of microbial protein synthesis for sheep given rations containing untreated wheat straw (UWS) and ammoniated wheat straw alone $(A W S)$ or with casein $(A W S C)$ or potato-protein (AWSP) supplements ${ }^{*}$

\begin{tabular}{lccccc}
\hline \multicolumn{1}{c}{ Ration ... } & UWS & AWS & AWSC & AWSP & SEM \\
\hline DAPA (mmol/kg DM) & $17 \cdot 2$ & $16 \cdot 5$ & $16 \cdot 5$ & $17 \cdot 4$ & $0 \cdot 49$ \\
AA (mol/kg DM) & $2 \cdot 87$ & $2 \cdot 68$ & $2 \cdot 81$ & $2 \cdot 99$ & 0.072 \\
N (g/kg DM) & $70 \cdot 2$ & $66 \cdot 7$ & $71 \cdot 0$ & $73 \cdot 6$ & $1 \cdot 57$ \\
AA-N (g/kg DM) & $48 \cdot 1$ & $44 \cdot 9$ & $47 \cdot 1$ & $50 \cdot 1$ & $1 \cdot 22$ \\
AA-N:N (g/kg) & $685^{\mathrm{b}}$ & $675^{\mathrm{ab}}$ & $663^{\mathrm{a}}$ & $683^{\mathrm{b}}$ & $4 \cdot 0$ \\
DAPA-N: N (g/kg) & $6 \cdot 88^{\mathrm{b}}$ & $6 \cdot 88^{\mathrm{b}}$ & $6 \cdot 50^{\mathrm{a}}$ & $6 \cdot 59^{\mathrm{ab}}$ & $0 \cdot 095$ \\
Microbial N pool associated with rumen fluid (g) & $2 \cdot 72^{\mathrm{a}}$ & $3 \cdot 44^{\mathrm{ab}}$ & $3 \cdot 02^{\mathrm{a}}$ & $4 \cdot 54^{\mathrm{b}}$ & $0 \cdot 373$ \\
Efficiency of microbial protein synthesis & & & & & \\
(g N/kg ARDOM) determined from $+:$ & & & & & \\
AA profiles & $23 \cdot 8^{\mathrm{a}}$ & $24 \cdot 5^{\mathrm{a}}$ & $37 \cdot 0^{\mathrm{c}}$ & $30 \cdot 4^{\mathrm{b}}$ & $1 \cdot 70$ \\
DAPA & $22 \cdot 7^{\mathrm{a}}$ & $23 \cdot 4^{\mathrm{a}}$ & $31 \cdot 6^{\mathrm{b}}$ & $31 \cdot 7^{\mathrm{b}}$ & $2 \cdot 35$ \\
Purine derivatives & $23 \cdot 3^{\mathrm{a}}$ & $30 \cdot 6^{\mathrm{b}}$ & $35 \cdot 8^{\mathrm{c}}$ & $33 \cdot 2^{\mathrm{bc}}$ & $1 \cdot 08$ \\
\hline \hline
\end{tabular}

a,b,c Means in a row with different superscript letters were significantly different $(P<0.05)$.

DAPA, diaminopimelic acid; AA, amino acids; ARDOM, apparently-rumen-degradable organic matter.

* For details of composition, see Tables 1 and 2.

$\dagger$ For details of procedures, see pp. 348-351.

\$ For details of methods, see p. 350 .

SBPP. Rumen DM disappearance values were 638,772 and $599 \mathrm{~g} / \mathrm{kg}$ for SBP, SBPC and SBPP respectively. Post-rumen and whole-tract $\mathbf{N}$ disappearance of all supplements was high, although higher for SBPC and SBPP than for SBP alone.

\section{Rumen microbes}

The AA profiles of ingested protein, endogenous protein (bovine pepsinogen), rumen microbes and duodenal digesta are given in Table 6. The microbial AA profile did not differ significantly between rations and no significant differences were observed between UWS and AWS with regard to the AA profiles of dietary intake and duodenal digesta; for presentation in Table 6 these AA profiles were combined. The computed proportions of microbial AA as a percentage of duodenal AA flow were significantly higher for AWSC and significantly lower for AWSP than for UWS and AWS. The proportion of endogenous AA in the duodenal protein flow did not differ between rations.

The composition of rumen microbes, the rumen microbial $\mathbf{N}$ pool calculated from the rumen fluid pool size and the DAPA concentration in rumen fluid, and the efficiency of microbial protein synthesis ( $\mathrm{g}$ microbial $\mathrm{N} / \mathrm{kg}$ apparently-rumen-degraded organic matter) are given in Table 7. No significant ration effects were observed for DAPA, AA, N or AA$\mathrm{N}$ concentrations in microbial DM. A significant ration effect was found for AA-N:N and DAPA-N:N, but differences were only small. AWSP had a significantly higher microbial $\mathrm{N}$ pool associated with rumen fluid than the other rations, which was mainly caused by differences in the rumen-fluid pool size. The DAPA concentration in the rumen fluid did not differ significantly between rations. Over rations the average DAPA concentration in rumen fluid was 0.113 (SEM 0.0152) $\mathrm{mmol} / 1$, which corresponded to an average concentration of microbial $\mathrm{N}$ in rumen fluid of 470 (SEM 10.7) $\mathrm{mg} / \mathrm{l}$.

Only the purine derivatives method showed a significantly higher efficiency of microbial protein synthesis for AWS than for UWS. Protein supplementation of AWS increased the 
Table 8. Intake and flow at the duodenum and ileum and faecal and urinary excretion of nitrogen of sheep given rations containing untreated wheat straw (UWS) and ammoniated wheat straw alone $(A W S)$ and with casein $(A W S C)$ and potato-protein $(A W S P)$ supplements ${ }^{*} \dagger$

\begin{tabular}{|c|c|c|c|c|c|}
\hline Ration... & UWS & AWS & AWSC & AWSP & SEM \\
\hline $\begin{array}{c}\text { Intake }(\mathrm{g} / \mathrm{d}) \\
\mathrm{N} \text { : Total } \\
\text { Straw } \\
\text { AA-N: Total } \\
\text { Straw }\end{array}$ & $\begin{array}{l}9 \cdot 0^{\mathrm{a}} \\
3 \cdot 3^{\mathrm{a}} \\
6 \cdot 0^{\mathrm{a}} \\
2 \cdot 0^{\mathrm{a}}\end{array}$ & $\begin{array}{c}16 \cdot 2^{\mathrm{b}} \\
10 \cdot 4^{\mathrm{bc}} \\
6 \cdot 7^{\mathrm{a}} \\
2 \cdot 7^{\mathrm{bc}}\end{array}$ & $\begin{array}{r}28 \cdot 2^{\mathrm{c}} \\
9 \cdot 6^{\mathrm{b}} \\
17 \cdot 6^{\mathrm{b}} \\
2 \cdot 5^{\mathrm{h}}\end{array}$ & $\begin{array}{c}30 \cdot 4^{c} \\
11 \cdot 8^{c} \\
16 \cdot 8^{b} \\
3 \cdot 1^{\mathrm{b}}\end{array}$ & $\begin{array}{l}0.86 \\
0.56 \\
0.68 \\
0.15\end{array}$ \\
\hline $\begin{array}{l}\text { Duodenal flow }(\mathrm{g} / \mathrm{d}) \\
\mathbf{N} \\
\text { AA-N } \ddagger \\
\text { Microbial } \\
\text { Feed } \\
\text { Endogenous } \\
\text { AA-N:N }\end{array}$ & $\begin{array}{r}15 \cdot 5^{\mathrm{a}} \\
10 \cdot 0^{\mathrm{a}} \\
6 \cdot 8^{\mathrm{a}} \\
3 \cdot 0^{\mathrm{a}} \\
0 \cdot 2^{\mathrm{a}} \\
647^{\mathrm{e}}\end{array}$ & $\begin{array}{c}21 \cdot 3^{\mathrm{b}} \\
11 \cdot 8^{\mathrm{ab}} \\
8 \cdot 4^{\mathrm{a}} \\
3 \cdot 2^{\mathrm{a}} \\
0 \cdot 2^{\mathrm{a}} \\
560^{\mathrm{a}}\end{array}$ & $\begin{array}{c}26 \cdot 0^{\mathrm{e}} \\
14 \cdot 3^{\mathrm{b}} \\
11 \cdot 7^{\mathrm{b}} \\
2 \cdot 4^{\mathrm{a}} \\
0 \cdot 2^{\mathrm{a}} \\
551^{\mathrm{a}}\end{array}$ & $\begin{array}{c}34 \cdot 7^{\mathrm{d}} \\
20 \cdot 8^{\mathrm{c}} \\
11 \cdot 0^{\mathrm{b}} \\
9 \cdot 4^{\mathrm{b}} \\
0 \cdot 4^{\mathrm{b}} \\
599^{\mathrm{c}}\end{array}$ & $\begin{array}{l}1.23 \\
0.83 \\
0.50 \\
0.43 \\
0.02 \\
5.0\end{array}$ \\
\hline $\begin{array}{l}\text { Ileal flow }(\mathrm{g} / \mathrm{d}) \\
\mathrm{N} \\
\text { AA-N } \\
\text { AA-N:N }\end{array}$ & $\begin{array}{r}7 \cdot 7^{\mathrm{a}} \\
4 \cdot 3^{\mathrm{a}} \\
553^{\mathrm{b}}\end{array}$ & $\begin{array}{l}11 \cdot 5^{\mathrm{b}} \\
5 \cdot 1^{\mathrm{ab}} \\
446^{\mathrm{a}}\end{array}$ & $\begin{array}{c}13 \cdot 1^{\mathrm{bc}} \\
5 \cdot 6^{\mathrm{b}} \\
432^{\mathrm{a}}\end{array}$ & $\begin{array}{r}15 \cdot 1^{\mathrm{c}} \\
6 \cdot 9^{\mathrm{c}} \\
454^{\mathrm{a}}\end{array}$ & $\begin{array}{l}0.66 \\
0.38 \\
6.7\end{array}$ \\
\hline $\begin{array}{l}\text { Faecal excretion }(\mathrm{g} / \mathrm{d}) \\
\mathrm{N}\end{array}$ & $6 \cdot 7^{\mathrm{a}}$ & $9 \cdot 7^{\mathrm{b}}$ & $10 \cdot 4^{\mathrm{bc}}$ & $11 \cdot 5^{\mathrm{c}}$ & 0.37 \\
\hline Urinary $N$ excretion $(g / d)$ & $3 \cdot 6^{\mathrm{a}}$ & $7 \cdot 1^{\mathrm{b}}$ & $17 \cdot 4^{\mathrm{d}}$ & $15 \cdot 9^{c}$ & $0 \cdot 30$ \\
\hline $\begin{array}{l}\text { N balance } \\
\text { mg/kg W } \\
\text { g/animal per } \mathrm{d}\end{array}$ & $\begin{array}{r}-61 \cdot 0^{\mathrm{a}} \\
-1 \cdot 3^{\mathrm{a}}\end{array}$ & $\begin{array}{r}-24 \cdot 9^{b} \\
-0 \cdot 6^{b}\end{array}$ & $\begin{array}{r}10 \cdot 2^{\mathrm{e}} \\
0.3^{\mathrm{c}}\end{array}$ & $\begin{array}{r}131 \cdot 0^{\alpha} \\
3 \cdot 0^{\alpha}\end{array}$ & $\begin{array}{l}5.18 \\
0.13\end{array}$ \\
\hline
\end{tabular}

a, b,c,a Means in a row with different superscript letters were significantly different $(P<0.05)$.

AA, amino acids.

* For details of composition, see Tables 1 and 2.

+ For details of procedures, see pp. 348-352.

‡ Based on AA profiles method; for details, see p. 350 .

efficiency of microbial protein synthesis significantly, although the difference was not significant for AWSP when measured by the purine derivatives method. Estimates of the efficiency of microbial protein synthesis for AWSC and AWSP only differed significantly when based on AA profiles. The purine derivatives method gave significantly higher estimates for efficiency of microbial protein synthesis than DAPA and AA profiles for AWS, while for AWSC the efficiency of microbial protein synthesis was significantly lower for DAPA than for AA profiles. The correlation coefficient between DAPA and AA profiles was $0.84(n 16, P<0.001)$, between DAPA and purine derivatives $0.62(n 16, P<$ $0.01)$ and between AA profiles and purine derivatives $0.63(n 16, P<0.01)$.

The difference in N intake between UWS and AWS was $7.2 \mathrm{~g} / \mathrm{d}$ (Table 8 ) of which $85 \%$ was a result of $\mathrm{N}$ added through $\mathrm{NH}_{3}$ treatment. The duodenal $\mathrm{N}$ and AA-N flows were higher than the intakes of these nutrients for all rations except for AWSC.

The AA profiles method, unlike the purine derivatives and DAPA methods, allowed division of the duodenal AA flow into subfractions of microbial, feed and endogenous origin. The duodenal AA flow of these fractions as given in Table 8 were based, therefore, on the AA profile method. Significantly higher estimates of microbial flows were observed 
Table 9. Apparent small-intestinal digestibility $(\mathrm{g} / \mathrm{kg})$ of rations containing untreated wheat straw (UWS) and ammoniated wheat straw alone $(A W S)$ or with casein $(A W S C)$ or potatoprotein (AWSP) supplements fed to sheep* ${ }^{*}$

\begin{tabular}{llllll}
\hline Ration ... & UWS & AWS & AWSC & AWSP & SEM \\
\hline N & $501^{\mathrm{a}}$ & $462^{\mathrm{a}}$ & $494^{\mathrm{a}}$ & $566^{\mathrm{b}}$ & $18 \cdot 1$ \\
AA-N & $573^{\mathrm{a}}$ & $571^{\mathrm{a}}$ & $604^{\mathrm{a}}$ & $671^{\mathrm{b}}$ & $13 \cdot 0$ \\
NPN & 366 & 322 & 359 & 408 & $28 \cdot 6$ \\
\hline
\end{tabular}

a. b Means in a row with different superscript letters were significantly different $(P<0.05)$.

AA, amino acids; NPN, non-protein-N.

* For details of composition of rations, see Tables 1 and 2.

$\dagger$ For details of procedures, see pp. 348-352.

Table 10. True small-intestinal digestibility $(T D)$ and endogenous ileal losses of individual amino acids $(A A)$, total $A A(T A A), A A-N, N$ and non-protein- $N(N P N)$ for sheep given rations containing untreated wheat straw $(U W S)$ and ammoniated wheat straw alone $(A W S)$ or with casein $(A W S C)$ or potato-protein $(A W S P)$ supplements* ${ }^{*}$

(Mean values with their standard errors)

\begin{tabular}{|c|c|c|c|c|c|}
\hline & \multicolumn{2}{|c|}{$\mathrm{TD}$} & \multicolumn{3}{|c|}{ Endogenous ileal loss $\ddagger$} \\
\hline & Mean & $\mathbf{S E}$ & Mean & $\mathrm{SE}$ & \\
\hline Cys & 0.67 & 0.073 & $6 \cdot 4$ & $1 \cdot 30$ & \\
\hline Asp & 0.84 & 0.016 & $32 \cdot 5$ & 2.67 & \\
\hline Met & 0.90 & 0.032 & $4 \cdot 1$ & 0.79 & \\
\hline Thr & 0.84 & 0.022 & 22.9 & 2.05 & \\
\hline Ser & 0.82 & 0.022 & 25.0 & 2.07 & \\
\hline Glu & 0.86 & 0.025 & $37 \cdot 4$ & 3.80 & \\
\hline Pro & 0.85 & 0.020 & $18 \cdot 7$ & $1 \cdot 33$ & \\
\hline Gly & 0.81 & 0.021 & $35 \cdot 3$ & 2.93 & \\
\hline Ala & 0.84 & 0.026 & 33.7 & $3 \cdot 56$ & \\
\hline Val & 0.88 & 0.018 & $27 \cdot 0$ & 1.89 & \\
\hline Ile & 0.89 & 0.015 & $15 \cdot 4$ & $1 \cdot 20$ & \\
\hline Leu & 0.90 & 0.018 & $23 \cdot 2$ & 1.99 & \\
\hline Tyr & 0.88 & 0.022 & $7 \cdot 9$ & 0.97 & \\
\hline Phe & 0.88 & 0.023 & $11 \cdot 2$ & 1.29 & \\
\hline His & 0.78 & 0.049 & $18 \cdot 8$ & $2 \cdot 23$ & \\
\hline Lys & 0.86 & 0.014 & $13 \cdot 3$ & 1.33 & \\
\hline Arg & 0.91 & 0.018 & 8.6 & 0.83 & \\
\hline Try & 0.76 & 0.047 & $2 \cdot 4$ & 0.57 & \\
\hline TAA & $0 \cdot 86$ & 0.018 & 350 & $26 \cdot 1$ & \\
\hline AA-N & 0.86 & 0.017 & 6.0 & $0 \cdot 44$ & \\
\hline \multirow[t]{2}{*}{$\mathbf{N}$} & $0-84$ & 0.032 & $11 \cdot 1$ & 0.69 & UWS \\
\hline & & & $14 \cdot 5$ & 0.83 & AWS, AWSC, AWSP \\
\hline \multirow[t]{2}{*}{ NPN } & $0 \cdot 68$ & 0.074 & 3.4 & 0.73 & UWS \\
\hline & & & $5 \cdot 8$ & $1 \cdot 10$ & AWS, AWSC, AWSP \\
\hline
\end{tabular}

* For details of composition, see Tables 1 and 2 .

$\dagger$ For details of procedures, see pp. 348-352.

$\ddagger \mathrm{mmol} / \mathrm{kg}$ non-protein DM (NPDM) for individual AA and TAA, g/kg NPDM for AA-N, N and NPN. 


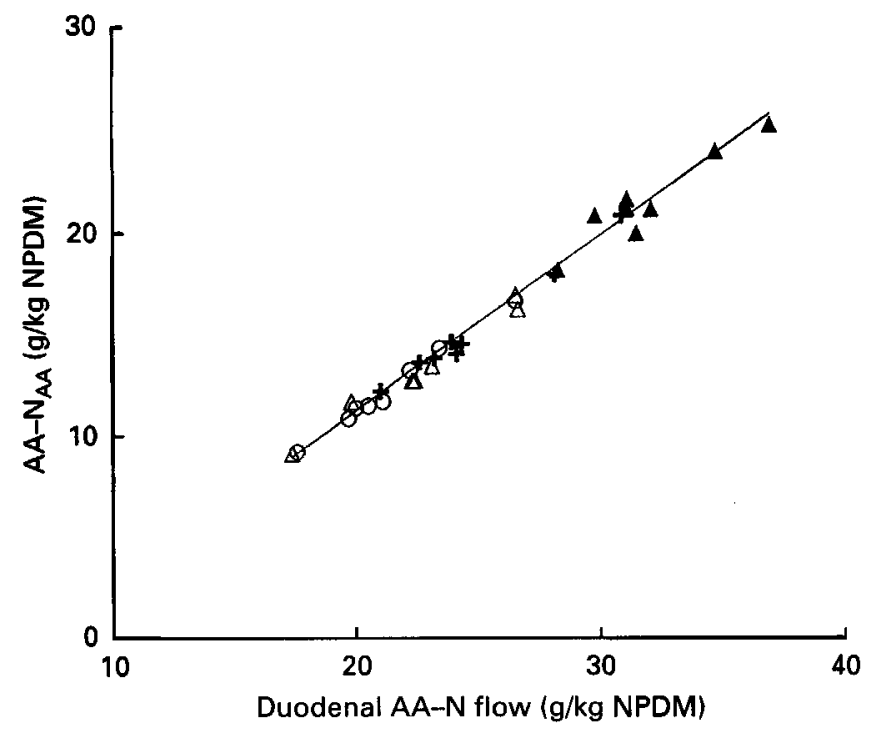

Fig. 2. True small-intestinal digestion of amino acid (AA)-N for rations containing untreated wheat straw (UWS) or ammoniated wheat straw alone (AWS) or with casein (AWSC) or potato-protein (AWSP) supplements fed to sheep. ( $\triangle)$, UWS; (O), AWS; (+), AWSC; (A), AWSP. Relationship between apparently small-intestinally absorbed AA-N (AA-N ${ }_{A A}$ ) and duodenal AA-N flow, both scaled to non-protein DM (NPDM). For details of rations and procedures, see Tables 1 and 2 and pp. 348-352.

for AWSC and AWSP than for AWS and UWS. AWSP had a significantly higher AA-N flow from feed origin and from endogenous origin than the other rations.

The AA-N: $N$ in duodenal digesta was significantly higher for UWS than for AWS and was significantly higher for AWSP than for AWS and AWSC. Estimates of the rumen digestion of AA-N from feed origin were $499,524,862$ and $444 \mathrm{~g} / \mathrm{kg}$ for UWS, AWS, AWSC and AWSP respectively (SEM $20.4 \mathrm{~g} / \mathrm{kg}$ ), when calculated from intake and duodenal flow of feed AA-N. The AA-N: $N$ ratio in ileal digesta was significantly higher for UWS than for the other rations. Some disappearance of $\mathrm{N}$ occurred between the terminal ileum and faeces. The average $\mathrm{N}$ disappearance in the large intestine was 183 (SEM 20.6) $\mathrm{g} / \mathrm{kg}$ ileal $\mathrm{N}$ flow, without any significant ration effect.

Regression of digestible $\mathbf{N}$ intake:organic matter intake $v . \mathbf{N}$ intake:organic matter intake gave estimates for metabolic faecal $\mathrm{N}$ excretion of 7.2 (SE 0.59$) \mathrm{g} / \mathrm{kg}$ organic matter intake and true whole-tract $\mathrm{N}$ digestion of 0.92 (SE 0.032). The residuals (digestible $\mathrm{N}$ intake:organic matter intake predicted minus digestible $\mathbf{N}$ intake:organic matter intake observed) were not significantly different from zero for any ration.

Urinary $\mathrm{N}$ excretion and $\mathrm{N}$ balances were significantly higher for AWS than for UWS. Protein supplementation to AWS increased urinary $\mathrm{N}$ excretion significantly, the increase being more for AWSC than for AWSP. Protein supplementation also increased $\mathrm{N}$ balance, although in this case the increase was significantly more for AWSP than for AWSC.

The apparent small-intestinal digestibilities of AA-N and $N$ were significantly higher for AWSP than for the other rations, while no significant ration effect was found for apparent small-intestinal digestibility of NPN (Table 9). Ration differences as found for apparent small-intestinal digestion of $\mathrm{N}$ and $\mathrm{AA}-\mathrm{N}$ were not found for true small-intestinal digestion (Table 10), indicating that ration differences with regard to apparent small-intestinal digestion were related to different duodenal NPDM and duodenal AA-N or N flows. The regression of apparent small-intestinal disappearance of individual AA, TAA, AA-N, N or 
NPN $v$. duodenal flow of these nutrients (Y and X scaled to NPDM) included all thirtytwo observations. By inclusion of ration as a factor in the regression model the existence of significant differences between rations with regard to endogenous ileal losses could be examined.

The NPDM flows were 463, 560, 586 and 659 (SEM 26.3) g/d for UWS, AWS, AWSC and AWSP respectively. Duodenal NPDM flows were significantly higher for AWS and AWSC than for UWS and significantly lower for AWS than for AWSP. For AA-N, TAA and individual AA no significant deviations from the general regression were observed, as illustrated in Fig. 2 for AA-N, while for $\mathrm{N}$ and NPN a significant ration effect was found (Table 10). No significant differences were observed between true small-intestinal digestibilities of $\mathbf{N}$ and AA-N, although NPN had a lower true digestibility than AA-N. Cystine, histidine and tryptophan had true digestibilities lower than 0.80 (Table 10). In addition, molar proportions in ileal endogenous protein losses of cystine and histidine were higher than those in duodenal protein resulting in even lower apparent small-intestinal digestibilities for these AA.

\section{DISCUSSION}

\section{Intake and digestion}

$\mathrm{NH}_{3}$ treatment of wheat straw increased straw intake significantly. The increased intake was associated with a significantly higher cell-wall digestion in the rumen and a higher rumen fluid volume and, because of the relatively constant rumen DM concentration (Owens \& Goetsch, 1986), also with a higher rumen DM fill; duodenal flows of undegraded cell walls and $k_{p}$ were unaffected.

The relative contribution of the rumen to whole-tract digestion of organic matter and cell-wall components of UWS and AWS were consistent with results for rations based on UWS and AWS reported by Van Bruchem et al. (1993). However, the results of the present experiment do not support the suggestion by Demeyer (1991) that the importance of hindgut fermentation increases with decreasing digestibility of the ration.

The proportion of organic matter digestion occurring in the rumen was higher for UWS and AWS (average $774 \mathrm{~g} / \mathrm{kg}$ ) in the present experiment than the value of $650 \mathrm{~g} / \mathrm{kg}$ observed by Zorilla-Rios et al. (1991) for AWS and UWS fed to cattle.

Protein supplementation of AWS reduced rumen cell-wall digestion; the reason for this is unknown. Rumen $\mathrm{pH}$, rumen VFA concentration and retention times in the rumen were approximately similar for AWS, AWSC and AWSP. Also, it is unlikely that the relatively high $\mathrm{NH}_{3}-\mathrm{N}$ concentration in the rumen fluid as found for AWSC and AWSP affected rumen digestion. Satter \& Slyter (1974) did not observe toxic effects of $\mathrm{NH}_{3}-\mathrm{N}$ concentrations up to $800 \mathrm{mg} / \mathrm{l}$ on microbial protein synthesis in vitro, and in the present experiment no negative effects of protein supplementation on efficiency of microbial protein synthesis were observed.

The lower rumen digestion of cell-wall components for protein-supplemented AWS was compensated by a higher large-intestinal digestion for hemicellulose, but not for cellulose.

Since the $k_{p}$ did not differ between rations AWS, AWSC and AWSP, the higher duodenal passage of NDF observed for AWSP is indicative of a higher rumen NDF fill and consequently a higher rumen DM fill. This was supported by the higher rumen fluid volume for sheep fed on AWSP compared with those fed on AWS or AWSC.

\section{Intake and protein status}

The fact that NDF intake was highly correlated with rumen fluid volume indicates that factors other than rumen fill were limiting intake of UWS, AWS and AWSC and possibly AWSP. Intake of roughages could be limited by the amount of protein available for 
absorption from the small intestine as suggested by Egan (1965, 1977), Doyle \& McLaren (1988) and Doyle \& Panday (1990), although no effects of increased small-intestinal protein availability were found in several other experiments (Kellaway \& Leibholz, 1983; Ketelaars \& Tolkamp, 1991). In the present experiment, digestible organic matter intake (DOMI) was linearly related to availability of truly absorbed AA-N (truly absorbed AA-N = duodenal AA-N flow $\times 0 \cdot 86$ ). Regression of truly absorbed AA-N $v$. DOMI with inclusion of the period effect as a factor yielded the following relationship (the intercept is the mean over periods, with the SE of the estimate):

truly absorbed AA-N (mg/kg W ${ }^{0.75}$ per d) $=-459$ (SE 163.9) + 33.0 (SE 5.27)

$$
\times \text { DOMI (g/kg W0.75 per d), }\left(r^{2} 0 \cdot 800, \operatorname{RSD} 89 \cdot 6, n 16\right) \text {. }
$$

The data, corrected for the period effect, are plotted in Fig. 3.

The basis of the hypothesis that the amount of protein available for absorption from the small intestine determines the intake of roughage could be that a balance is required between net energy and net protein availability to the tissues. DOMI could represent the net energy availability to the tissues. The conversion of DOMI to net energy probably occurs at a rather constant efficiency for ad lib.-fed rations, because (1) digestible energy intake is closely related to DOMI, (2) the metabolizable energy content in digestible energy is approximately 0.80 without much variation between different feeds (Agricultural Research Council, 1980; Oosting et al. 1993a) and (3) the efficiency of conversion of metabolizable energy to net energy for $a d$ lib. rations fed to growing animals is also fairly constant (0-6) as postulated by Tolkamp \& Ketelaars (1993), and confirmed by Oosting et al. (1993a) for UWS and AWS in sheep and cattle. In the present experiment, DOMI and $\mathrm{N}$ balance were linearly related. The $\mathrm{N}$ balance $v$. DOMI regression was done with inclusion of the period effect as a factor in the regression model. The following equation (the intercept is the mean over periods, with the SE of estimate) was found:

$$
\begin{aligned}
\mathrm{N} \text { balance }\left(\mathrm{mg} / \mathrm{kg} \mathrm{W}^{0.75} \text { per } \mathrm{d}\right)=-460 & (\mathrm{SE} 81 \cdot 0)+15 \cdot 4(\mathrm{SE} 2 \cdot 60) \\
& \times \text { DOMI }\left(\mathrm{g} / \mathrm{kg} \mathrm{W}^{0.75} \text { per d), } r^{2} 0 \cdot 773, \text { RSD } 44 \cdot 3, n 16 .\right.
\end{aligned}
$$

The data corrected for the period effect are plotted in Fig. 4.

The equation predicts a zero $\mathrm{N}$ balance for a DOMI of $29 \cdot 7 \mathrm{~g} / \mathrm{kg} \mathrm{W}^{0.75}$ per d, higher than the maintenance requirements of $26 \mathrm{~g}$ DOMI $/ \mathrm{kg} \mathrm{W}^{\mathbf{0} 75}$ per d (Agricultural Research Council, 1980). Although the regression coefficient has a high standard error, it is remarkably close to values observed by others for small ruminants fed on roughage-based diets. Ketelaars \& Tolkamp (1991) observed a value of $14.4 \mathrm{mg} \mathrm{N}$ balance/g DOMI for West African Dwarf goats. Recalculation of results of Elliott \& Topps (1964), who measured total digestible nutrient (TDN) intake and $\mathrm{N}$ balance in Blackhead Persian sheep, and Egan (1965), who measured digestible energy intake in Merino sheep receiving dietary $\mathrm{N}$ supplements, resulted in estimates of 14.6 and $15.3 \mathrm{mg} \mathrm{N}$ balance/g DOMI respectively. TDN values given by Elliott \& Topps (1964) were converted to digestible organic matter by assuming that $1 \mathrm{~g}$ TDN contains $0.95 \mathrm{~g}$ digestible organic matter, and the regression coefficient derived from the regression of digestible energy intake $v$. $N$ balance as given by Egan (1965) was converted to the regression coefficient of $\mathrm{N}$ balance $v$. DOMI by assuming $18.8 \mathrm{~kJ}$ digestible energy intake/g DOMI and that $\mathrm{b}_{x, y} \mathrm{~b}_{y, x}=r^{2}$. Larger regression coefficients (up to $20.9 \mathrm{mg} \mathrm{N}$ balance/g DOMI) were found by Grenet \& Demarquilly (1977) for Texel sheep. The linearity of these relationships between DOMI and $\mathrm{N}$ balance suggests that net protein and net energy availabilities to the tissues are balanced in ad lib. rations, hence that voluntary DOMI cannot increase without a concomitant increase in net protein availability. However, Ørskov (1982) proposed that energy intake may increase without increased $\mathrm{N}$ balance, if $\mathrm{N}$ availability becomes limiting. 


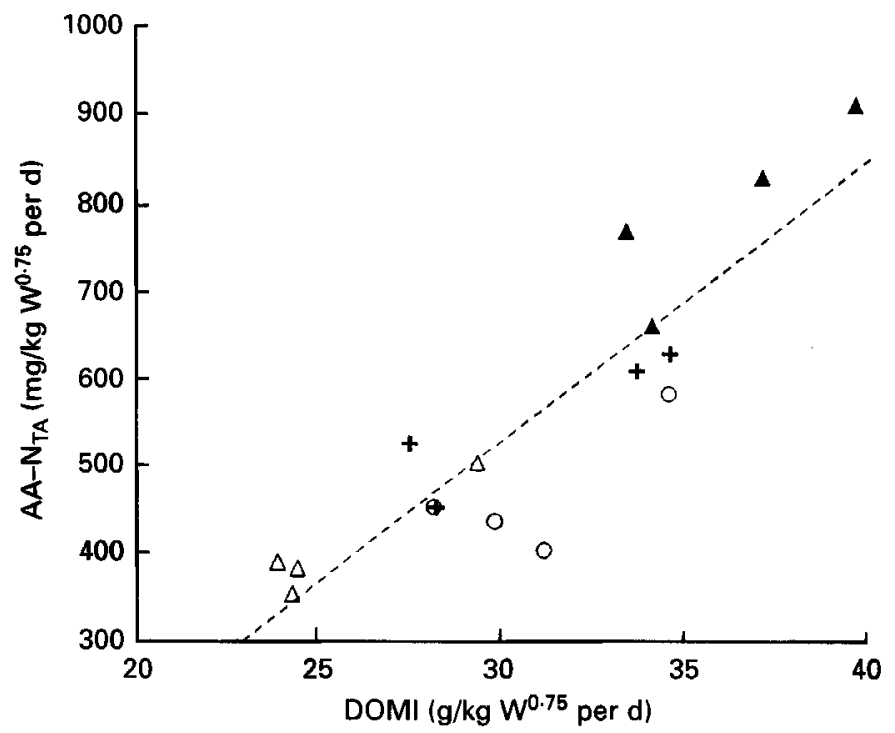

Fig. 3. Relationship between truly small-intestinally absorbed amino acid (AA)-N (AA- $N_{T A}$ ) and digestible organic matter intake (DOMI; data corrected for period effect) for rations containing untreated wheat straw (UWS) or ammoniated wheat straw alone (AWS) or with casein (AWSC) or potato-protein (AWSP) supplements fed to sheep. $(\triangle)$, UWS; $(O)$, AWS; $(+)$, AWSC; (A), AWSP. For details of rations and procedures, see Tables 1 and 2 and pp. 348-352. W, live weight.

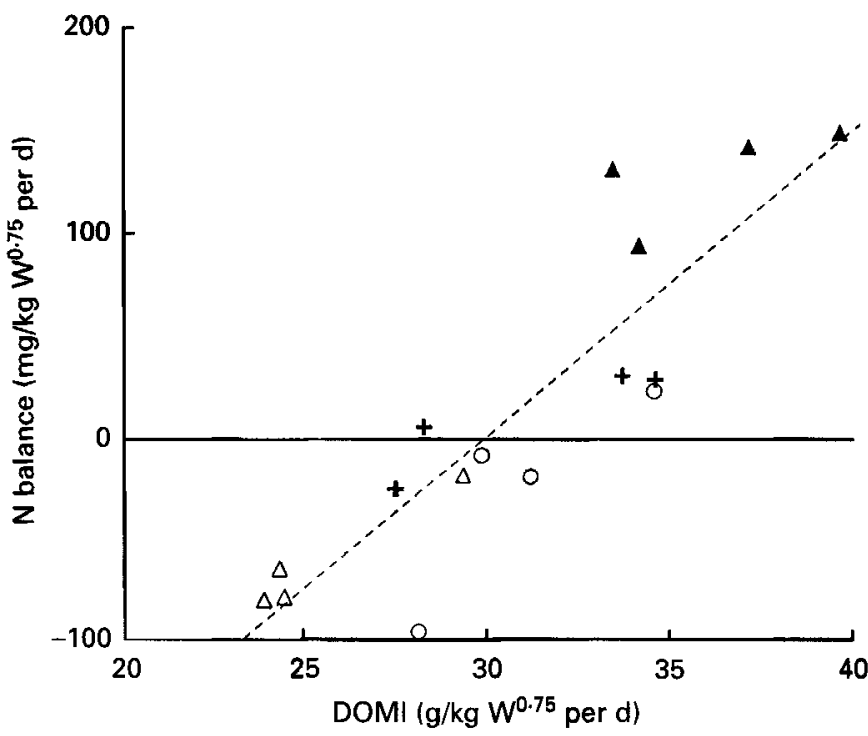

Fig. 4. Relationship between $\mathrm{N}$ balance and digestible organic matter intake (DOMI; data corrected for period effect) for rations containing untreated wheat straw (UWS) or ammoniated wheat straw alone (AWS) or with casein (AWSC) or potato-protein (AWSP) supplements fed to sheep. $(\triangle)$, UWS; (O), AWS; $(+)$, AWSC; $(\mathbf{\Delta})$, AWSP. For details of rations and procedures, see Tables 1 and 2 and pp. 348-352. W, live weight. 


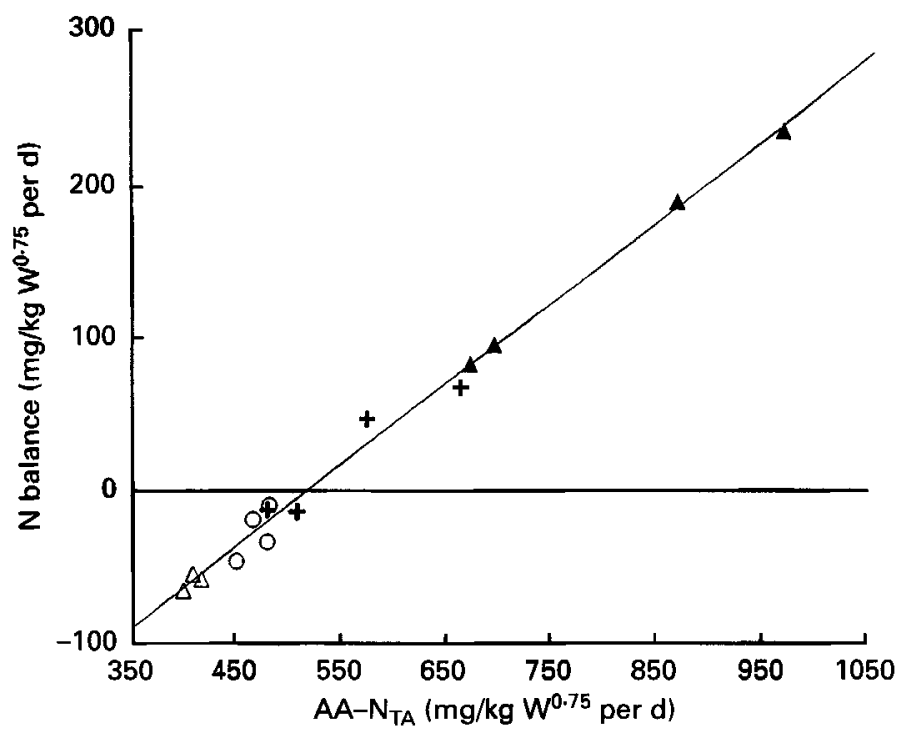

Fig. 5. Relationship between $N$ balance and truly small-intestinally absorbed amino acid (AA)-N (AA- $N_{T A}$; data corrected for animal and period effect) for rations containing untreated wheat straw (UWS) or ammoniated wheat straw alone (AWS) or with casein (AWSC) or potato-protein (AWSP) supplements fed to sheep. ( $\triangle$ ), UWS; (O), AWS; (+), AWSC; (A), AWSP. For details of rations and procedures, see Tables 1 and 2 and pp. 348-352. $W$, live weight.

The efficiency of utilization of truly absorbed AA-N was estimated by regression of $\mathrm{N}$ balance $v$. truly absorbed AA-N with inclusion of the (significant) animal and period effects as factors in the regression model. The regression equation obtained was (the intercept is averaged over animals and periods, with the SE of the estimate):

$\mathrm{N}$ balance $\left(\mathrm{mg} / \mathrm{kg} \mathrm{W}^{0.75}\right.$ per $\left.\mathrm{d}\right)=-281(\mathrm{SE} 15.9)+0.54($ SE 0.029)

$\times$ truly absorbed AA-N (mg/kg W ${ }^{0.75}$ per d), $r^{2} 0.989$, RSD $14 \cdot 3, n 16$.

The data, corrected for the animal and period effect are plotted in Fig. 5.

The intercept can be interpreted as the obligatory $\mathrm{N}$ loss in the form of endogenous urinary $\mathrm{N}$ and metabolic faecal $\mathrm{N}$. This value of $281 \mathrm{mg} / \mathrm{kg} \mathrm{W}^{0.75}$ per $\mathrm{d}$ is in the range of values varying from 201 to $427 \mathrm{mg} / \mathrm{kg} \mathrm{W}^{0.75}$ per d given by Ørskov (1982) for total urinary and faecal $\mathrm{N}$ excreted by fasting sheep or sheep maintained on $\mathrm{N}$-free diets. Estimates of the intercept for individual animals ranged from -242 to $-323 \mathrm{mg} / \mathrm{kg} \mathrm{W}^{0.75}$ per $\mathrm{d}$ and for periods from -221 to $-344 \mathrm{mg} / \mathrm{kg} \mathrm{W}^{\mathbf{0 . 7 5}}$ per $\mathrm{d}$. With increasing period number the value for the intercept increased, indicating that the maintenance requirements decreased with increasing duration of the experiment. The regression coefficient implies an efficiency of utilization of truly-absorbed AA-N of 0.54 for all rations.

Hence, because (1) literature and the results of the present experiment suggest that a balance is required between net protein and net energy availability in growing animals and (2) the efficiency of utilization of truly absorbed AA-N was similar for all rations in the present experiments, it seems justified to conclude that a balance was required between truly absorbed AA-N and DOMI in the present experiment, i.e. that DOMI was limited by the availability of truly absorbed AA-N. 
However, truly absorbed AA-N and $\mathrm{N}$ balance are in part a function of DOMI. Truly absorbed AA-N of microbial origin and, to a lesser extent originating from undegraded straw protein, increase with increasing straw DOMI. However, from microbial AA-N production per $\mathrm{kg}$ DOMI apparently degraded in the rumen, the proportion of DOMI that is apparently degraded in the rumen and a true small-intestinal digestion of microbial AA$\mathrm{N}$ of $\mathbf{0 . 8 6}$, it can be calculated that for ration AWSC (the ration with the highest efficiency of microbial protein synthesis) only $14.0 \mathrm{~g}$ microbial truly absorbed AA-N could be produced per kg DOMI. This quantity is insufficient to achieve the required retention of $15 \mathrm{~g} \mathrm{~N} / \mathrm{kg}$ DOMI (Fig. 4). Hence, additional straw consumption in the case of ration AWSC would result in an unbalanced net protein: net energy ratio, unless the quantity of feed truly absorbed AA-N increased considerably, which is unlikely in the case of AWS.

Why limited protein availability to the tissues restricts voluntary intake is unknown. MacRae \& Lobley (1982) and MacRae et al. (1985) reported that the efficiency of metabolizable energy utilization increased, and consequently the $\mathrm{O}_{2}$ consumption per unit metabolizable or net energy ingested decreased, with increasing protein availability. Tolkamp \& Ketelaars (1992) postulated, as a control mechanism for intake regulation, that ruminants minimize $\mathrm{O}_{2}$ consumption per unit net energy intake. These authors reported that the net energy intake level where the $\mathrm{O}_{2}$ consumption per unit net energy ingested is minimal, increases with increasing efficiency of utilization of metabolizable energy. Hence, increased protein availability to the tissues could increase the efficiency of metabolizable energy utilization and consequently increase the voluntary intake.

\section{Rumen microbes and small-intestinal protein digestion}

In an earlier experiment (Oosting et al. 1993 b) the efficiency of microbial protein synthesis was (average of DAPA and AA profiles methods) 24.6 and $19.0 \mathrm{~g} \mathrm{~N} / \mathrm{kg}$ digestible organic matter apparently degraded in the rumen for UWS and AWS respectively. This value for AWS was lower than that from the present experiment, possibly because additional minerals including $S$ were supplied in the present experiment.

The concentration of rumen microbes in rumen fluid did not differ significantly between rations. Ration differences in fluid-associated microbial pools could be attributed to differences in rumen fluid pools. The proportion of the total microbial pool associated with the fluid phase may vary from 20 to $47 \%$ (Owens \& Goetsch, 1986). Oosting et al. (1993b) observed for UWS as well as for AWS, that $36 \%$ of the microbial pool was associated with the fluid phase.

As discussed by Oosting et al. (1993b), the DAPA method may give higher, lower or similar estimates of the efficiency of microbial protein synthesis compared with the AA profiles method. In the present experiment no significant differences were found between these two methods, except for ration AWSC. The purine derivatives method differed significantly from the other two methods only for ration AWS. Despite the variation between methods it could be concluded that the casein and potato-protein supplements supplied nutrients, probably peptides and/or branched-chain AA, that were limiting microbial growth with AWS and UWS.

From the true rumen degradability of feed $A A-N$, it was calculated that rumen $\mathrm{NH}_{3}-\mathrm{N}$ contributed $63,58,0$ and $33 \%$ to net microbial AA-N production for UWS, AWS, AWSC and AWSP respectively. Oosting et al. $(1993 \mathrm{~b})$ reported values of 59 and $67 \%$ for UWS and AWS respectively. These results indicate that in rations with a limited rumen true protein availability the maximum contribution of $\mathrm{NH}_{3}-\mathrm{N}$ to microbial protein synthesis may approximate $60-70 \%$. The remaining contribution has to be provided by dietary true protein. The possible difference in the efficiency of microbial protein synthesis between AWSC and AWSP even indicates that the efficiency of microbial protein synthesis is higher 
when all microbial AA-N can be synthesized from dietary protein as with AWSC, compared with AWSP where $33 \%$ of microbial AA-N originated from rumen $\mathrm{NH}_{3}$.

The true small-intestinal protein digestion of 0.86 observed in the present experiment is consistent with the values reported by Van Bruchem et al. $(1989 ; 0.85$ for roughage-based diets in sheep) and by Storm et al. (1983) for AA of microbial origin. The major part of duodenal protein flow consists of microbial protein, which explains the similarity between the results from various experiments, but it could be concluded from the present experiment that dietary AA added through potato-protein supplementation were digested to the same extent as microbial protein. Although measured in cattle, the high small-intestinal digestion of $\mathrm{N}$ from Dacron bags introduced into the duodenum and collected in faeces also indicated that $\mathrm{N}$ from the supplements was highly digestible in the lower gut. The smallintestinal disappearances of $\mathrm{N}$ from Dacron bags observed in the present experiment for UWS $(652-774 \mathrm{~g} / \mathrm{kg})$ as well as for AWS $(607-750 \mathrm{~g} / \mathrm{kg})$ were considerably higher than those for untreated $(317 \mathrm{~g} / \mathrm{kg})$ and ammoniated barley straw $(357 \mathrm{~g} / \mathrm{kg})$ reported by Hvelplund (1989).

Sheep fed on UWS had lower NPN losses per $100 \mathrm{~g}$ NPDM from the ileum than sheep fed on rations based on AWS. This could probably be attributed to the fact that part of the $\mathrm{N}$ added through $\mathrm{NH}_{3}$ treatment was not available for digestion. This is supported by the lower AA-N:N value in duodenal digesta for AWS and AWSC compared with UWS. The results of Oosting et al. (1993 b) also suggested that part of the $\mathrm{N}$ added through $\mathrm{NH}_{3}$ treatment could not be digested. Barnes (1988) observed by near i.r. diffuse reflectance spectrometry that $\mathrm{NH}_{3}$ treatment leads to the formation of amide groups with both cellwall and non-cell-wall components of wheat straw. It is likely that part of these amide groups is not digestible. However, as indicated by disappearance of $\mathrm{N}$ from Dacron bags over the whole digestive tract, potentially $800-900 \mathrm{~g} / \mathrm{kg}$ total $\mathrm{N}$ in AWS could be digested, although it is possible that this could be attributed partly to solubilization.

Recalculation of the data from the experiment by Van Bruchem et al. (1989) by a model without intercept yielded as an estimate of ileal endogenous AA-N losses $7.9 \mathrm{mg} / \mathrm{g}$ NPDM for sheep fed on roughage-based diets of a relatively high quality. Oosting et al. (1993b) estimated ileal endogenous AA-N losses at $5.0 \mathrm{mg} / \mathrm{g}$ NPDM for sheep fed on UWS or AWS supplemented with sugarbeet pulp, while in the present experiment ileal endogenous AA-N losses were estimated at $6.0 \mathrm{mg} / \mathrm{g}$ NPDM. This indicates that sheep fed on strawbased diets have lower ileal endogenous protein losses than sheep fed on diets of higher quality with higher protein contents. Whether this is a result of a lower endogenous secretion in the distal part of the ileum or to higher re-absorption of secreted endogenous AA remains to be investigated.

The authors gratefully acknowledge financial support provided by the Commission of the European Communities: Contract TS2-0091-NL, Utilization of crop residues and supplementary feeds in tropical developing countries. They are further indebted to A. Waanders, S. C. W. Lammers-Wienhoven, L. J. G. M. Bongers, P. J. M. Vlemmix, I. van Langevelde, C. P. Leffering, H. Romkema, J. Draaijer, H. Jansen, K. Bosma, M. van der Spoel, F. Dooper, C. Gursus and W. van Straalen who contributed to this experiment.

\section{REFERENCES}

Agricultural Research Council (1980). The Nutrient Requirements of Ruminant Livestock. Slough: Commonwealth Agricultural Bureaux.

Barnes, R. J. (1980). Near infra-red spectra of ammonia-treated straw and of isolated cell walls. Animal Feed Science and Technology 21, 209-218.

Brouwer, B. O. (1989). DBSTAT User's Guide. Wageningen, The Netherlands: Department of Animal Husbandry, Wageningen Agricultural University. 
Chen, X. B., Hovell, F. D. DeB, Orskov, E. R. \& Brown, D. S. (1990a). Excretion of purine derivatives by ruminants: effect of endogenous nucleic acid supply on purine derivative excretion by sheep. British Journal of Nutrition 63, 131-142.

Chen, X. B., Mathieson, J., Hovell, F. D. DeB. \& Reeds, P. J. (1990b). Measurement of purine derivatives in urine of ruminants using automated methods. Journal of the Science of Food and Agriculture 53, 23-33.

Chen, X. B., Ørskov, E. R. \& Hovell, F. D. DeB. (1991). The use of intragastric infusion in studies on excretion of purine derivatives as a measure of protein supply in ruminants. In Protein Metabolism and Nutrition, European Association of Animal Production Publication no. 59, vol. 2, short communications, pp. 67-70 [B. O. Eggum, S. Boisen, C. Børsting, A. Danfaer and T. Hvelplund, editors]. Foulum, Denmark: National Institute of Animal Science.

Demeyer, D. I. (1991). Quantitative aspects of microbial metabolism in the rumen and hindgut. In Rumen Microbial Metabolism and Ruminant Digestion, pp. 217-239 [J. P. Jouany, editor]. Paris: INRA.

Doyle, P. T. \& McLaren, C. E. (1988). Utilization of clover diets by sheep. II. Intake, digestion and utilisation of nitrogen and sulfur. Australian Journal of Agricultural Research 39, 881-890.

Doyle, P. T. \& Panday, S. B. (1990). The feeding value of cereal straws for sheep. III. Supplementation with minerals or minerals and urea. Animal Feed Science and Technology 29, 29-43.

Egan, A. R. (1965). Nutritional status and intake regulation in sheep. III. The relationship between improvement of nitrogen status and increase in voluntary intake of low-protein roughages by sheep. Australian Journal of Agricultural Research 16, 463-472.

Egan, A. R. (1977). Nutritional status and intake regulation in sheep. VII. Relationships between the voluntary intake of herbage by sheep and the protein/energy ratio in the digestion products. Australian Journal of Agricultural Research 28, 907-915.

Elliott, R. C. \& Topps, J. H. (1964). Effects of various low protein diets on the distribution of ruminal nitrogen and on the nitrogen required for maintenance of African sheep. Animal Production 6, 345-355.

Faichney, G. J. (1980). The use of markers to measure digesta flow from the stomach of sheep fed once daily. Journal of Agricultural Science, Cambridge 94, 313-319.

Grenet, E. \& Demarquilly, C. (1977). Utilisation de l'azote des fourrages vertes par le mouton en croissance: influence du stade de végétation, de l'espèce fourragère, de la fertilisation azotée et de l'addition d'orge (utilization of fresh forage by growing sheep: influence of stage of maturity, forage type, nitrogen fertilization and barley supplementation). Annales de Zootechnie 26, 481-501.

Grovum, W. L. \& Williams, V. J. (1973). Rate of passage of digesta in sheep. 4. Passage of marker through the alimentary tract and the biological relevance of rate constants from the changes in concentration of marker in faeces. British Journal of Nutrition 30, 313-329.

Hespell, R. B. \& Bryant, M. P. (1979). Efficiency of rumen microbial growth: influence of some theoretical and experimental factors on $\mathrm{Y}_{\mathrm{ATP}}$. Journal of Animal Science 49, 1640-1659.

Hoover, W. H. (1986). Chemical factors involved in ruminal fiber digestion. Journal of Dairy Science 69, 2755-2766.

Hvelplund, T. (1989). Protein evaluation of treated straws. In Evaluation of Straws in Ruminant Feeding, pp. 66-74 [M. Chenost and P. Reiniger, editors]. Barking, Essex: Elsevier Science Publishers Ltd.

Kellaway, R. C. \& Leibholz, J. (1983). Effects of nitrogen supplements on intake and utilization of low-quality forages. World Animal Review 48, 33-37.

Ketelaars, J. J. M. H. \& Tolkamp, B. J. (1991). Toward a new theory of feed intake regulation. PhD Thesis, Agricultural University Wageningen, The Netherlands.

MacRae, J. C. \& Lobley, G. E. (1982). Some factors which influence thermal energy losses during the metabolism of ruminants. Livestock Production Science 11, 447-456.

MacRae, J. C., Smith, J. S., Dewey, P. J. S., Brewer, A. C., Brown, D. S. \& Walker, A. (1985). The efficiency of utilization of metabolizable energy and apparent absorption of amino acids in sheep given spring- and autumnharvested dry grass. British Journal of Nutrition 54, 197-209.

Oosting, S. J., Boekholt, H. A., Los, M. J. M. \& Leffering, C. P. (1993a). Intake and utilization of energy from ammonia-treated and untreated wheat straw by steers and wether sheep fed a basal diet of grass pellets and hay. Animal Production 57, 227-236.

Oosting, S. J., Viets, T. C., Lammers-Wienhoven, S. C. W. \& van Bruchem, J. (1993b). Ammonia treatment of wheat straw. 2. Efficiency of microbial protein synthesis, rumen microbial protein pool size and turnover, and small intestinal protein digestion in sheep. Netherlands. Journal of Agricultural Science 41, 135-151.

Oosting, S. J., Vlemmix, P. J. M. \& van Bruchem, J. (1994). Effect of ammonia treatment of wheat straw with or without supplementation of potato protein on intake, digestion and kinetics of comminution, rumen degradation and passage in steers. British Journal of Nutrition 72, 147-165.

Ørskov, E. R. (1982). Protein Nutrition in Ruminants. London: Academic Press Inc. Ltd., Harcourt Brace Jovanovich Publishers.

Owens, F. N. \& Goetsch, A. L. (1986). Digesta passage and microbial protein synthesis. In Control of Digestion and Metabolism in Ruminants, pp. 196-227 [L. P. Milligan, W. L. Grovum and A. Dobson, editors]. Englewood Cliffs, NJ: Prentice Hall. 
Satter, L. D. \& Slyter, L. L. (1974). Effect of ammonia concentration on rumen microbial protein production in vitro. British Journal of Nutrition 32, 199-208.

Siddons, R. C., Beever, D. E. \& Nolan, J. V. (1982). A comparison of methods for the estimation of microbial nitrogen in duodenal digesta of sheep. British Journal of Nutrition 48, 377-389.

Snedecot, G. W. \& Cochran, W. G. (1967). Statistical Methods. Ames, USA: The Iowa State University Press.

Storm, E., Brown, D. S. \& Ørskov, E. R. (1983). The nutritive value of rumen micro-organisms in ruminants. 3. The digestion of microbial amino and nucleic acids in, and losses from, the small intestine of sheep. British Journal of Nutrition 50, 479-485.

Tolkamp, B. J. \& Ketelaars, J. J. M. H. (1992). Toward a new theory of feed intake regulation in ruminants. 2. Costs and benefits of feed consumption: an optimization approach. Livestock Production Science 30, $297-317$.

Tolkamp, B. J. \& Ketelaars, J. J. M. H. (1993). The effect of ad lib feeding on the efficiency of energy utilization in growing and lactating cattle. Animal Production 56, 431-432.

Udén, P., Colluci, P. E. \& van Soest, P. J. (1980). Investigation of chromium, cerium and cobalt as markers in digesta. Journal of the Science of Food and Agriculture 31, 625-632.

Van Bruchem, J., Bongers, L. J. G. M., Lammers-Weinhoven, S. C. W., Bangma, G. A. \& van Adrichem, P. W. M. (1989). Apparent and true digestibility of protein and amino acids in the small intestine of sheep as related to the duodenal passage of protein and non-protein dry matter. Livestock Production Science 23, 317-327.

Van Bruchem, J., Oosting, S. J., Lammers-Wienhoven, S. C. W. \& Leffering, C. P. (1993). Ammonia treatment of wheat straw. 1. Voluntary intake, chewing behaviour, rumen pool size and turnover and partition of digestion along the gastro-intestinal tract of sheep. Netherlands Journal of Agricultural Science 41, 111-133.

Van Soest, P. J. (1982). Nutritional Ecology of the Ruminant. Corvallis, Oregon: O \& B books.

Zorrilla-Rios, J., Horn, G. W. \& McNew, R. W. (1991). Nutritive value of ammoniated wheat straw fed to cattle. Journal of Animal Science 69, 283-294. 